\title{
Checklist to the Elatostema (Urticaceae) of Vietnam including 19 new records, ten new combinations, two new names and four new synonyms
}

\author{
Long-Fei Fu ${ }^{1}$, Alex Monro ${ }^{2}$, Truong Van Do ${ }^{3}$, Maxim S. Nuraliev ${ }^{4,5}$ ， Leonid V. Averyanov ${ }^{6}$, Fang Wen ${ }^{1}$, \\ Zi-Bing Xin ${ }^{1}$, Tatiana V. Maisak ${ }^{6}$, Andrey N. Kuznetsov ${ }^{4,7}$, Svetlana P. Kuznetsova ${ }^{4}$, Khang Sinh Nguyen ${ }^{8}$, \\ Yi-Gang Wei Corresp. 1 \\ ${ }^{1}$ Guangxi Key Laboratory of Plant Conservation and Restoration Ecology in Karst Terrain, Guangxi Institute of Botany, Guangxi Zhuang Autonomous \\ Region and Chinese Academy of Sciences, Guilin, China \\ 2 Identification and Naming Department, Herbarium, Royal Botanic Gardens, Kew, London, United Kingdom \\ 3 Department of Biology, Vietnam National Museum of Nature, Vietnam Academy of Science and Technology, Hanoi, Vietnam \\ 4 Joint Russian-Vietnamese Tropical Scientific and Technological Center, Hanoi, Vietnam \\ 5 Department of Higher Plants, Biological Faculty, M.V. Lomonosov Moscow State University, Moscow, Russia \\ 6 Komarov Botanical Institute of the Russian Academy of Sciences, St Petersburg, Russia \\ 7 Severtsov Institute of Ecology and Evolution Problems of the Russian Academy of Sciences, Moscow, Russia \\ 8 Institute of Ecology and Biological Resources, Vietnam Academy of Science and Technology, Hanoi, Vietnam \\ Corresponding Author: Yi-Gang Wei \\ Email address: weiyigang@aliyun.com
}

Elatostema (Urticaceae) comprises several hundred herbaceous species distributed in tropical and subtropical Africa, Asia, Australia and Oceania. The greatest species richness occurs on limestone karst in Southeast Asia. Taxonomic revisions of Elatostema are largely out of date and contradict each other with respect to the delimitation of Elatostema and Pellionia. Most herbaria in SE Asia and worldwide contain significant amounts of unidentified material. As part of a broader revision of Elatostema in SE Asia, we present an updated checklist for Vietnam based on field visits, a review of specimens in herbaria worldwide, a review of type material and nomenclature. We recognize 77 taxa (75 species and two intraspecific taxa) of Elatostema in Vietnam, 23 of which were previously ascribed to Pellionia. Nineteen of these are new records for the country, i.e. E. attenuatoides, $E$. austrosinense, E. backeri, E. brunneinerve, E. crassiusculum, E. crenatum, $E$. fengshanense, E. glochidioides, E. malacotrichum, E. nanchuanense, E. oblongifolium, E. obtusum, E. oppositum, E. pergameneum, E. prunifolium, E. pseudolongipes, E. pycnodontum, E. salvinioides and $E$. xichouense. We place $E$. baviensis in synonymy of $E$. platyphyllum, E. colaniae in synonymy of $E$. myrtillus, P. macroceras in synonymy of $E$. hookerianum, and $P$. tetramera in synonymy of $E$. dissectum for the first time. Fourteen taxa (18\% of all the recognized taxa) are endemic to Vietnam, which makes Elatostema one of the richest genera for endemic species in this country; this level of endemism is comparable to levels observed in Orchidaceae. Our checklist suggests that the highest 
diversity and endemism of Elatostema occurs in northern Vietnam, and that there is the greatest floristic similarity of northern Vietnam to SW China. The relationship among floristic regions is also investigated. We could find no records of Elatostema for 33 out of 63 provincial units of Vietnam, including all the southernmost provinces. We propose that further studies on the diversity of Elatostema in central and southern Vietnam are severely needed. 
1 Checklist to the Elatostema (Urticaceae) of Vietnam including 19 new records, ten new

2 combinations, two new names and four new synonyms

3 Long-Fei Fu ${ }^{1}$, Alex Monro ${ }^{2}$, Truong Van Do ${ }^{3}$, Maxim S. Nuraliev ${ }^{4}, 5$, Leonid V. Averyanov ${ }^{6}$, Fang

4 Wen $^{1}$, Zi-Bing Xin ${ }^{1}$, Tatiana V. Maisak ${ }^{6}$, Andrey N. Kuznetsov ${ }^{4}$, , Svetlana P. Kuznetsova ${ }^{4}$,

$5 \quad$ Khang Sinh Nguyen ${ }^{8} \&$ Yi-Gang Wei ${ }^{1}$

$6{ }^{1}$ Guangxi Key Laboratory of Plant Conservation and Restoration Ecology in Karst Terrain,

7 Guangxi Institute of Botany, Guangxi Zhuang Autonomous Region and Chinese Academy of

8 Sciences, Guilin, China

$9{ }^{2}$ Identification and Naming Department, Herbarium, Royal Botanic Gardens, Kew, London, UK

$10{ }^{3}$ Department of Biology, Vietnam National Museum of Nature, Vietnam Academy of Science and

11 Technology, Hanoi, Vietnam

$12{ }^{4}$ Joint Russian-Vietnamese Tropical Scientific and Technological Center, Hanoi, Vietnam

$13{ }^{5}$ Department of Higher Plants, Biological Faculty, M.V. Lomonosov Moscow State University, 14 Moscow, Russia.

$15{ }^{6}$ Komarov Botanical Institute of the Russian Academy of Sciences, St Petersburg, Russia

$16{ }^{7}$ Severtsov Institute of Ecology and Evolution Problems of the Russian Academy of Sciences, 17 Moscow, Russia

$18{ }^{8}$ Institute of Ecology and Biological Resources, Vietnam Academy of Science and Technology, 19 Hanoi, Vietnam.

Corresponding Author:

22 Yi-Gang Wei ${ }^{1}$

No. 85, Yanshan Street, Yanshan Town, Guilin, Guangxi, CN-541006, China

Email address: weiyigang@aliyun.com 
Abstract: Elatostema (Urticaceae) comprises several hundred herbaceous species distributed in tropical and subtropical Africa, Asia, Australia and Oceania. The greatest species richness occurs on limestone karst in Southeast Asia. Taxonomic revisions of Elatostema are largely out of date and contradict each other with respect to the delimitation of Elatostema and Pellionia. Most herbaria in SE Asia and worldwide contain significant amounts of unidentified material. As part of a broader revision of Elatostema in SE Asia, we present an updated checklist for Vietnam based on field visits, a review of specimens in herbaria worldwide, a review of type material and nomenclature. We recognize 77 taxa (75 species and two intraspecific taxa) of Elatostema in

\section{Introduction}


Elatostema J.R.Forst. \& G.Forst. (Urticaceae) comprises several hundred species of succulent herbs and subshrubs that grow in shade in forests, gorges, stream sides and caves (Fu et al., 2017; Monro et al., 2018). There are currently 626 accepted names within the genus Elatostema (The Plant List, 2018). Elatostema is most diverse in subtropical and tropical climates and is characterized by apparently alternate (opposite but frequently with ephemeral and occasionally absent nanophylls), strongly asymmetrical leaves arranged distichously, small staminate flowers borne in dense cymes with receptacle-like involucres or paniculate cymes and minute pistillate flowers borne in dense capitate cymes, the bracts of which form a receptacle-like involucre (Tseng et al., in press). As in most species in the tribe Elatostemateae (Conn \& Hadiah, 2009), the stamens open explosively and the seeds are ejected by reflexive staminodes (Friis, 1989). Elatostema is distributed throughout tropical and subtropical Africa, Madagascar, Asia, Australia and Oceania, with highest diversity on limestone karst in China and Southeast Asia (Yahara, 1984; Lahav-Ginott \& Cronk, 1993; Wang \& Chen, 1995; Lin, Friis \& Wilmot-Dear, 2003; Wang, 2014). The previous studies suggest that this diversity has been driven by the challenges of colonising karst substrates, which once overcome leads to species radiations (Chung et al., 2014; Fu et al., 2017), and that past temperature fluctuations and East Asian monsoons have driven the rates of plant diversification in karst ecosystems by accelerating the rate of karstification (Kong et al., 2017).

Vietnam comprises $331,000 \mathrm{~km}^{2}$ of the eastern Indochinese Peninsula between latitudes $8^{\circ}$ and $24^{\circ} \mathrm{N}$, and longitudes $102^{\circ}$ and $110^{\circ} \mathrm{E}$. Mountains account for $40 \%$ of the surface area, and ca. $42 \%$ of the land is forested (De Queiroz et al., 2013). Vietnam's climate divides broadly into humid subtropical in the north, monsoon in the centre and tropical savannah in the south (Peel, Finlayson \& McMahon, 2007). However, on the basis of more detailed and accurate climate classification by Nguyen et al. (2000), seven types of climate are defined in Vietnam (Fig. 1) which are largely congruent with the floristic region classification (Takhtajan, 1978; Takhtajan, 1986; Averyanov et al., 2003a). Within Vietnam, six floristic regions have been delimited: the Sikang-Yunnan, South Chinese, North Indochinese, Central Annamese, South Annamese and 
82 South Indochinese Floristic Regions (Fig. 2). Vietnam also forms part of the Indo-Burma biodiversity hotspot and hosts 110 Key Biodiversity Areas (Mittermeier et al., 2004), and 65 Important Bird Areas (BirdLife International, 2002). Its flora comprises ca. 12,000 vascular plant species (Averyanov et al., 2003a), of which ca. 10\% are endemic to the country (Pilgrim \& Tu, 2007). Despite Vietnam's rich plant diversity, it is still poorly sampled, with only ca. 14 specimen records per $100 \mathrm{~km}^{2}$ (Newman et al., 2007). A comparison of the 20 most species-rich families for neighbouring southern China places Urticaceae in the top ten most species-rich families (Zhu, 2017), yet it is absent from the top 20 families for Vietnam (Zhu, Yan \& Qin, 2003). This suggests that Urticaceae are undersampled in Vietnam.

The delimitation of Elatostema has been controversial with respect to Elatostematoides C.B.Rob., Pellionia Gaudich. and Procris Comm. ex Juss. Using reconstruction of molecular phylogeny and re-evaluation of morphological characters of leaves, inflorescences and flowers, the latest study (Tseng et al., in press) demonstrates that Elatostema is a monophyletic group which includes Pellionia but excludes Procris, Elatostematoides and Pellionia repens (Lour.) Merr.

Despite the large number of species descriptions and numerous revisions of Elatostema in China (Wang, 1980; Wang \& Chen, 1995; Lin et al., 2003; Wei et al., 2011; Wang, 2014; Wang, 2016), there has been little work on the Southeast Asian taxa (Robinson, 1910; Gagnepain, 1930; Yahara, 1984; Beaman, 2001; Ho, 2003; Hiep, 2005). In addition, the most recent world-scale revision of this genus was undertaken in the 1930s before much of the region had been extensively covered by collections (Schroeter \& Winkler, 1935; Schroeter \& Winkler, 1936). Lack of taxonomic effort combined with high species diversity of Elatostema, high rate of species discovery and the frequency of point endemism has resulted in many Southeast Asian and world herbaria having significant numbers of undetermined Elatostema collections. The lack of a comprehensive species and distribution list for Elatostema in Vietnam therefore represents a barrier not only to its study but also to the assessment of extinction threats, conservation and sustainable use. 
111 documented 35 species and 32 species (together with Pellionia) respectively. Since that time

112 further 27 species have been recorded from Vietnam in regional floras and checklists and other

113

114

115

116

117

118

119

120

121

122

123

124

125

126

127

128

129

130

131

132

133

134

135 works (Wang, 1983; Wang \& Chen, 1995; Lin, Friis \& Wilmot-Dear, 2003; Lin, 2008; Lin et al., 2011; Fu et al., 2013; Fu et al., 2014a; Fu et al., 2014b; Lin, Duan \& Bi, 2014a; Lin, Duan \& Bi, 2014b; Wang, 2014; Do et al., 2017) and several species have had their circumscription changed (Shao, Lin \& Duan, 2004; Wang, 2016). The generic placement of some species was also reevaluated (see above). Considering these numerous additions, our ongoing research in Southeast Asian Elatostema, the recently revised genus circumscription (Tseng et al., in press) and the need to critically assess the extinction threat of the species we decided to produce an updated checklist to support further taxonomic and broader scientific studies.

\section{Materials \& Methods}

Fieldtrips were undertaken by two groups, a Sino-Vietnamese Group (SVG) and a RussianVietnamese Group (RVG). Between 2012 and 2017, SVG undertook five fieldtrips to the provinces or cities of Bac Kan, Cao Bang, Ha Giang, Ha Noi, Hai Phong, Hoa Binh, Nghe An, Lang Son, Lao Cai, Ninh Binh, Quang Binh, Thanh Hoa, Tuyen Quang and Vinh Phuc in northern Vietnam. During the course of these trips SVG made ca. 100 Elatostema collections. Over the last 30 years RVG has undertaken dozens of fieldtrips throughout Vietnam, which have resulted in ca. 200 Elatostema collections. In addition to field collecting we reviewed ca. 1000 specimens of Elatostema at A, BM, GXMI, HN, IBK, IBSC, K, KUN, LE, MHA, MO, MPU, MW, P, PE, SING, TAI and VNMN. This was accompanied by a literature review which encompassed species protologues, the most recent monographs (Schroeter \& Winkler, 1935; Schroeter \& Winkler, 1936), and regional checklists (Robinson, 1910; Gagnepain, 1930; Backer, 1965; Yahara, 1984; Ho, 2003; Hiep, 2005; Wang, 2014; Wang, 2016). Using these sources of information, we have generated a preliminary species list. We then confirmed or refuted each name on the list against 
136

137

138

139

140

141

142

143

144

145

146

147

148

149

150

151

152

153

154

155

156

157

158

159

160

161

162

type material, either the original specimens or high resolution images of them, using the subscription-based full version of The JSTOR Global Plants portal (2017) and online databases of some well-digitized herbaria (e.g. E, K, P, PE) and consulting original description of each species so that only names for which a herbarium specimen or field image could be confidently associated with a type image or specimen or original description were included in the final checklist.

We used the morphological species concepts (Schroeter \& Winkler, 1935; Schroeter \& Winkler, 1936; Wang, 1980; Wei, Monro \& Wang, 2011; Wang, 2014) to delimit species. These concepts place emphasis on peduncle bract shape and length, the number, morphology and arrangement of the bracts comprising the receptacle-like involucre, the number of bracteoles per flower and leaf lamina length/width ratios. Material was examined under a Changfang XTL-240 binocular microscope and Planapo lens at $\times 14$ to $\times 90$ magnifications.

For counting the diversity and endemism of Elatostema across floristic regions, we followed the concepts of Takhtajan (1978; Takhtajan, 1986) and Averyanov et al. (2003a) to assign the location of each specimen to particular floristic region. The specimens without detailed localities that could not be assigned with confidence to a floristic region were not used in this analysis.

\section{Results}

Diversity \& endemism

We document 77 taxa of Elatostema in Vietnam, 14 taxa (18\%) of which are endemic to the country. These taxa comprise 75 species, two of which are represented each by two taxa of a lower level (varieties and subspecies). Table 1 provides a summary of the species richness, national endemism, and new national records identified here, per floristic region. Figures 3-5 provide field images of a representative sample of these species.

We document the greatest species richness in northern Vietnam (Cao Bang, Ha Giang, Lao Cai provinces) and the lowest species richness in eight scattered provinces across northern to central Vietnam and 25 southernmost provincial units where no Elatostema species have been documented: Bac Ninh, Ha Nam, Hai Duong, Hung Yen, Nam Dinh, Thai Binh, Yen Bai (North), 
163

164

165

166

167

168

169

170

171

172

173

174

175

176

177

178

179

180

181

182

183

184

185

186

187

188

189

Da Nang City (Central) and An Giang, Ba Ria-Vung Tau, Bac Lieu, Ben Tre, Binh Dinh, Binh Duong, Binh Phuoc, Binh Thuan, Ca Mau, Can Tho City, Dak Nong, Dong Nai, Dong Thap, Hau Giang, Ho Chi Minh City, Kien Giang, Long An, Ninh Thuan, Phu Yen, Quang Ngai, Soc Trang, Tay Ninh, Tien Giang, Tra Vinh, and Vinh Long (South, Fig. 6). We recovered the greatest number of species endemic to the country in northern Vietnam (particularly Bac Kan province and Ha Noi City) (Fig. 6).

\section{Relationship among floristic regions}

Figure 7 provides the proportion of diversity and endemism and the relationship of each floristic region. The order of the proportion of diversity of two floristic regions is the following: South Chinese - North Indochinese (49.2\%) > Sikang-Yunnan - North Indochinese (46.9\%) > SikangYunnan - South Chinese (35.8\%) > Central Annamese - South Annamese $(35.3 \%)>$ North Indochinese - Central Annamese (30.0\%) > South Chinese - Central Annamese (20.7\%) > North Indochinese - South Annamese (19.4\%) > Sikang-Yunnan - South Annamese (13.2\%) > South Chinese - South Annamese (13.0\%) > Sikang-Yunnan - Central Annamese (10.6\%).

New records, new combinations, new names \& synonymy

We found 19 new records of Elatostema for Vietnam, i.e. E. attenuatoides W.T.Wang, E. austrosinense Y.H.Tseng \& A.K.Monro nom. nov., E. backeri H.Schroet., E. brunneinerve W.T.Wang, E. crassiusculum W.T.Wang, E. crenatum W.T.Wang, E. fengshanense W.T.Wang \& Y.G.Wei, E. glochidioides W.T.Wang, E. malacotrichum W.T.Wang \& Y.G.Wei, E. nanchuanense W.T.Wang, E. oblongifolium Fu, E. obtusum Wedd., E. oppositum Q.Lin \& Y.M.Shui, E. pergameneum W.T.Wang, E. prunifolium W.T.Wang, E. pseudolongipes W.T.Wang \& Y.G.Wei, E. pycnodontum W.T.Wang, E. salvinioides W.T.Wang, and E. xichouense W.T.Wang. All new records came from the northern provinces: Cao Bang, Ha Giang, Lao Cai, Dien Bien, Lang Son, Phu Tho, Bac Kan, Hoa Binh and Ninh Binh (Table 1); all of them are also known from the neighbouring regions of China, i.e. Guangxi, Guizhou and Yunnan. Of the 
Vietnamese provinces, Cao Bang and Ha Giang had the greatest number of new records.

We place Elatostema baviensis Gagnep. in synonymy of E. platyphyllum Wedd. based on the characters of large lamina $(10-25 \times 4-7.5 \mathrm{~cm})$ with auriculate base, large stipule $(15-25 \times 3-5.5$ $\mathrm{mm}$ ) and pistillate inflorescence with short peduncle and obvious receptacle. Then, we place $E$. colaniae Gagnep. in synonymy of E. myrtillus Hand.-Mazz. based on the characters of small lamina $(13-28 \times 6-10 \mathrm{~mm})$ with auriculate base and furfuraceous stem base. We also place Pellionia macroceras Gagnep. in synonymy of E. hookerianum Wedd. based on the characters of falcate lamina with cordate base. Finally, we place $P$. tetramera Gagnep. in synonymy of $E$. dissectum Wedd. based on the characters of oblong-lanceolate lamina and staminate inflorescence with long peduncle. In addition and in line with the study by Tseng et al. (in press), we transfer all previously known Pellionia species found in Vietnam (except for P. repens) to Elatostema including ten new combinations and two new names proposed accordingly.

\section{Discussion}

Diversity \& endemism

Our checklist of Elatostema in Vietnam doubles the number of species cited in the most recent checklist (Hiep, 2005) bringing the total diversity to 77 taxa ( 75 species). This is the product of both recent checklists for the region, field collecting and herbarium specimen examination, aided by the availability of protologues, type images and other collections online (e.g. The JSTOR Global Plants portal, 2017; Seregin, 2018).

We also document that species richness and endemism increase with latitude, away from the equator. Whilst counter-intuitive, a similar pattern has been documented for the diversity of Begonia L. (Averyanov \& Nguyen, 2012) and Orchidaceae (Averyanov et al., 2003a). This is likely a reflection of the distribution of karst in Vietnam with which Elatostema (Wang 2014), Primulina Hance (Kong et al., 2017) and Begonia (Chung et al., 2014) species richness in Southeast Asia is strongly associated rather than Elatostema's preference for a more seasonal or cooler climate. Given the total absence of Elatostema records from Vietnam's southernmost 
217 provinces this pattern may also have been over-emphasised by unequal sampling effort across the 218 country as well as by unequal distribution of intact vegetation. Indeed, the southernmost provinces 219 are largely plain and therefore occupied by agricultural landscapes.

220 The documented 18\% level of endemism of the Elatostema taxa in Vietnam is nearly twice

221

222

223

224

225

226

227

228

229

230

231

232

233

234

235

236

237

238

239

240

241

242

243

the average for the country's flora $(10 \%$, Pilgrim \& Tu, 2007) and comparable to that in the most species-rich family Orchidaceae (19\%, Averyanov et al., 2003a). However, this level is still lower than the corresponding level in Guizhou (39\%), Guangxi (64\%) and Yunnan (71\%) of China, which are well documented (Wang, 2014). As in China, an association with karst is likely the driver for much of this diversity indicating Vietnam's capacity of higher endemism which is likely to be revealed when Elatostema is comprehensively documented. Current researches (Chung et al., 2014; Kong et al., 2017) suggest that rates of karstification over time, and likely in the Miocene, associated with seasonal climate and temperature, may have driven speciation on karst. Species that were able to adapt to what is a relatively inhospitable substrate speciating as karst habitat was formed. It is notable that of the documented genera that have 'radiations' associated with karst, i.e. Begonia, Impatiens L., Primulina and Elatostema, all are mostly herbaceous, three of the four are succulent, three of the four are insect-pollinated and all have seeds that are abiotically rather than animal dispersed.

\section{Comparison of diversity among floristic regions, and reasons of its differences}

Among the six floristic regions delimited in Vietnam (see Fig. 2; Takhtajan, 1978; Takhtajan, 1986; Averyanov et al., 2003a), we found the greatest species richness and endemism in the South Chinese Floristic Region (Figs. 6-7; see Table 1). We attribute this to widespread presence of karst, monsoon tropical climate with cold winter and summer rains and tropical forests (Fig. 2) with which Elatostema species richness and endemism is known to be associated (Wang, 2014). For example, the checklist of Elatostema in China documented 184 out of the 280 species recorded as restricted to karst, many of which are range-restricted endemics (Wang, 2014). A similar pattern in species richness in Vietnam has been documented for Begonia by Averyanov \& Nguyen (2012) 
244

245

246

247

248

249

250

251

252

253

254

255

256

257

258

259

260

261

262

263

264

265

266

267

268

269

270

who also ascribe part of this richness to the presence of karst in this floristic region.

The second highest species diversity and endemism occurred in Sikang-Yunnan Floristic Region. Notably, this region occupies one of the smallest areas in Vietnam, comparable only with the area of South Annamese Region; this indicates extraordinarily high average Elatostema species density in the Sikang-Yunnan Floristic Region. This region lies within the SSE extension of the Himalayan Highlands. It can be compared with another representative Himalayan area, i.e. Xizang province, which is the fourth most species-rich province for Elatostema in China (Wang, 2014). Within Sikang-Yunnan Floristic Region, 17 species of Elatostema (22.7\% of the species that we document for Vietnam) occur in Hoang Lien Son Range of Lao Cai province. It is notable that Sikang-Yunnan Floristic Region is the only one within the territory of Vietnam which represents the Holarctic floristic kingdom, while the other five regions belong to the Paleotropical floristic kingdom (Takhtajan, 1978; Takhtajan, 1986; Averyanov et al., 2003a; Averyanov et al., 2003b). This explains the high diversity of Elatostema in this region, as this genus is also known to be mostly associated with the southern part of the Holarctic kingdom (Wang, 2014).

The next most important floristic region for species richness and endemism of Elatostema in Vietnam is the North Indochinese Floristic Region (Fig. 7; Table 1). It possesses the same species number as the previous region and a single national endemic species instead of two. This region covers a chain of continuous limestone plateaux (Averyanov et al., 2003a). Monsoon tropical climate with cold winter and summer rains is typical of the largest part of the northern portion (Fig. 2) which is similar to those found in the South Chinese Region. Therefore, the diversity and endemism of this floristic region share similar pattern to the South Chinese Region which is congruent with our result that nearly half of species $(49.2 \%)$ co-existed. This region also includes the southern extension of the Himalayan Highlands and our result revealed $46.9 \%$ co-existed species (Fig. 7) between it and Sikang-Yunnan Region, which also suggests their similarity. It should also be taken into account that North Indochinese Floristic Region occupies almost the largest area within Vietnam, comparable only with the area of South Indochinese Region. Therefore the high species diversity in this region is also an effect of its large territory. 
We found low species richness and endemism in the Central Annamese Floristic Region (Fig.

272

273

274

275

276

277

278

279

280

281

282

283

284

285

286

287

6; see Table 1). The representative provinces of this floristic region are Quang Tri and Thua ThienHue which contain karst mountains and a climate very similar to that of the North Indochinese Floristic Region (Averyanov et al., 2003a); besides, 30.0\% of species co-occurred in these two floristic regions (Fig. 7). We would therefore expect species richness and endemism in Central Annamese Floristic Region to be similar to those in the North Indochinese Floristic Region rather than lower (Table 1). We would also expect the diversity to be higher (rather than the same) in the Central Annamese Floristic Region than in the South Annamese Floristic Region, as the latter lacks karst and experiences drier climate. We also found 31.3\% species shared between Central Annamese and South Annamese Floristic Regions. Therefore we propose that both of these phenomena reflect a lack of collecting effort.

South Indochinese Floristic Region, the largest in Vietnam (Fig. 2), comprises lowland area of 23 provincial units and yet we document no species records from all of them (Fig. 6). This is unlikely to be due to the absence of karst, edaphic factors or climate alone. Whilst this floristic region has little karst (Kien Giang province only), it does have multiple climate types (Fig. 1) and significant forest cover (Global Forest Watch, 2014) which elsewhere in SE Asia would support a diversity of Elatostema species (Robinson, 1910; Conn, 2008). Again we propose that this absence of records is the result of a lack of collecting effort rather than a consequence of total absence of this genus. This inference is also supported by the absence of known Elatostema collections from several Vietnamese provinces surrounded by areas with rather high diversity of this genus: Yen Bai, Thai Binh, Nam Dinh, Bac Ninh, Hai Duong, Hung Yen, Ha Nam, Da Nang, Quang Ngai and Binh Dinh. We therefore propose that South Indochinese Floristic Region should be of a high priority for subsequent studies of Elatostema in Vietnam.

\section{Conclusions}

This study combines taxonomic and field expertise from China, Russia, the United Kingdom and Vietnam. It has strongly benefited from the availability of type images online which has 
298

299

300

301

302

303

304

305

306

307

308

309

310

311

312

313

314

315

316

317

318

319

320

321

322

323

324

accelerated the process of identification and the evaluation of taxon names. Ongoing research to document the floras of Cambodia, Laos, Thailand and Vietnam provides a huge opportunity for the taxonomy of Elatostema. Once combined with the completed Flora of China and Flora Malesiana accounts our updated checklist for Vietnam will fill a significant knowledge gap for this speciesrich genus and lay the foundations for a global checklist. This fourth checklist for Vietnam not only doubles estimates of the diversity of the genus, it also identifies major knowledge gaps for the country, i.e. central Vietnam and most notably, southern Vietnam. We propose that greater sampling effort of the flora of central Vietnam and southern Vietnam will result in a number of new additions to the flora of the country.

\section{Acknowledgements}

We are grateful to Dr. Jer-Ming Hu from National Taiwan University and Dr. Lei Wu from Central South University of Forestry and Technology for providing specimens, to Dr. Xin Hong from Anhui University for joining the fieldtrip and to the curators at A, BM, GXMI, HN, IBK, IBSC, K, KUN, LE, MHA, MO, MPU, MW, P, PE, SING, TAI and VNMN for their help in checking specimens.

\section{References}

Averyanov LV, Loc PK, Hiep NT, Harder DK. 2003a. Phytogeographic review of Vietnam and adjacent areas of Eastern Indochina. Komarovia 3: 1-83.

Averyanov LV, Loc PK, Hiep NT, Doan DT. 2003b. Highland vegetation and flora of Van Ban District, Lao Cai province in northern Viet Nam. Turczaninowia 6: 47-86.

Averyanov L, Cribb PJ, Phan KL, Nguyen TH. 2003c. Slipper orchids of Vietnam: with an introduction to the Flora of Vietnam. Kew: Royal Botanic Gardens, Kew 308p.

Averyanov LV, Nguyen HQ. 2012. Eleven new species of Begonia L. (Begoniaceae) from Laos and Vietnam. Turczaninowia 15: 5-32.

Backer CA. 1965. Elatostema. In: Backer CA \& Bakhuizen van den Brink Jr RC, Eds. Flora of 
325

326

327

328

329

330

331

332

333

334

335

336

337

338

339

340

341

342

343

344

345

346

347

348

349

350

351

Java, vol. 2. N v P. Noordhoff, Groningen, 42-44.

Beaman RS. 2001. Phylogeny and biogeography of Elatostema (Urticaceae) from Mount Kinabalu. Sabah Parks Nature Journal 4: 71-93.

BirdLife International. 2002. Directory of IBAs in Vietnam. Available at http://www.birdlifeindochina.org/datazone/12 (accessed 30 May 2013).

Chung KF, Leong WC, Rubite R, Repin R, Kiew R, Liu Y, Peng CI. 2014. Phylogenetic analyses of Begonia sect. Coelocentrum and allied limestone species of China shed light on the evolution of Sino-Vietnamese karst flora. Botanical Studies 55: 1-15 DOI 10.1186/19993110-55-1.

Conn BJ. 2008. Census of vascular plants of Papua New Guinea. Available at http://www.pngplants.org/PNGCensus (accessed 23 March 2018).

Conn BJ, Hadiah JT. 2009. Nomenclature of tribes within the Urticaceae. Kew Bulletin 64:349352 DOI 10.1007/s12225-009-9108-4.

De Queiroz JS, Griswold D, Nguyen DT, Hall P. 2013. Vietnam tropical forest and biodiversity assessment. USAID Vietnam.

Do VT, Lin Y, Tran NH, Wei YG. 2017. Elatostema kimhyense (Urticaceae), a new species from Vietnam. Bulletin of Botanical Research 37: 321-324.

Friis I. 1989. Urticaceae. In: Polhill RM, ed. Flora of tropical East Africa. Rotterdam: A.A. Balkema, 1-64.

Fu LF, Do VT, Wen F, Liu SY, Wei YG. 2013. New records of Elatostema and Pellionia (Urticaceae) from Vietnam. Guihaia 33: 801-803.

Fu LF, Do VT, Wen F, He CX. 2014a. Elatostema arcuatobracteatum (Urticaceae), a new species from Vietnam. Phytotaxa 174: 111-115 DOI 10.11646/phytotaxa.174.2.6

Fu LF, Huang SL, Liu Y, Do VT, Wen F, Wei YG. 2014b. A newly recorded species of Elatostema (Urticaceae) from Vietnam. Taiwania 59: 281-286 DOI 10.6165/tai.2014.59.281.

Fu LF, Su LY, Mallik A, Wen F, Wei YG. 2017. Cytology and sexuality of 11 species of Elatostema (Urticaceae) in limestone karsts suggests that apomixis is a recurring 
352

353

354

355

356

357

358

359

360

361

362

363

364

365

366

367

368

369

370

371

372

373

374

375

376

377

378

phenomenon. Nordic Journal of Botany 35: 251-256 DOI 10.1111/njb.01281.

Gagnepain F. 1928. Pellionia nouveaux d'Indo-Chine. Bulletin de la Société Botanique de France 75: 917-928 DOI 10.1080/00378941.1928.10837115.

Gagnepain F. 1929. Quelques Elatostema et un Procris nouveaux d'Indo-Chine. Bulletin de la Société Botanique de France 74: 80-82 DOI 10.1080/00378941.1929.10837147.

Gagnepain F. 1930. Pellionia Gaudich. In: Lecomte MH, Ed. Flore générale de l'Indo-Chine. Masson et Cie, Paris, 5: 892-921.

Global Forest Watch. 2014. Interactive Map. World Resources Institute. Available from: www.globalforestwatch.org (accessed: 10 January 2018).

Hiep NT. 2005. Urticaceae Juss. 1789. In: Ban NT, Ed. Checklist of plant species of Vietnam, vol. 3. Agriculture Publishing House, Hanoi, 209-226.

Ho PH. 2003. An Illustrated Flora of Vietnam Vol. 2. NXB Tre Press, Ho Chi Minh, 589-593.

Kong H, Condamine FL, Harris AJ, Chen J, Pan B, Möller M, Hoang VS, Kang M. 2017. Both temperature fluctuations and East Asian monsoons have driven plant diversification in the karst ecosystems from southern China. Molecular Ecology 26: 6414-6429 DOI 10.1111/mec. 14367 .

Lahav-Ginott S, Cronk QCB. 1993. The mating system of Elatostema (Urticaceae) in relation to morphology: a comparative study. Plant Systematics and Evolution 186: 135-145 DOI 10.1007/BF00940793.

Lin Q. 2008. A revision of Elatostema section Weddelia series Salvinioida (Urticaceae). Botanical Journal of the Linnean Society 158: 62-66 DOI 10.1111/j.1095-8339.2008.00848.x.

Lin Q, Duan LD, Yang ZR. 2009. Lectotypifications of thirty-one names in Elatostema (Urticaceae). Acta Botanica Boreali-Occidentalla Sinica 29: 1909-1914.

Lin Q, Friis I, Wilmot-Dear MC. 2003. Pellionia \& Elatostema. In: Wu Z, Raven PH, Eds. Flora of China, vol. 5. Science Press, Beijing and Missouri Botanical Garden Press, St. Louis, 74189.

Lin Q, Yang ZR. 2010. Lectotypifications of thirteen names in Pellionia (Urticaceae). Bulletin of 
Botanical Research 30: 4-7.

380

381

382

383

384

Lin Q, Yang ZR, Duan LD, Gao TG. 2011. Miscellaneous taxonomic notes on Elatostema (Urticaceae) from China and its adjacent area. Nordic Journal of Batany 29:590-597 DOI 10.1111/j.1756-1051.2011.01060.x.

Lin Y, Duan LD, Bi HY. 2014a. Two newly recorded species of Pellionia (Urticaceae) from Vietnam. Guihaia 34: 673-674.

Lin Y, Duan LD, Bi HY. 2014b. A new variety and two new records of Elatostema J. R. Forster \& G. Forster (Urticaceae) from Vietnam. Bangladesh Journal of Plant Taxonomy 21(1):27-32 DOI 10.3329/bjpt.v21i1.19254.

Mittermeier RA, Robles Gil P, Hoffmann M, Pilgrim JD, Brooks TM, Mittermeier CG, Fonseca GAB da. 2004. Hotspots revisited: Earth's biologically richest and most endangered terrestrial ecoregions. Cemex, Mexico.

Monro AK, Bystriakova N, Fu L, Wen F, Wei Y. 2018. Discovery of a diverse cave flora in China. Plos One 13: e0190801 DOI 10.1371/journal.pone.0190801.

Newman M, Ketphanh S, Svengsuksa B, Thomas P, Sengdala K, Lamxay V, Armstrong K. 2007. A Checklist of the Vascular Plants of Lao PDR. Royal Botanic Garden Edinburgh Press, Edinburgh.

Nguyen KV, Nguyen TH, Phan KL, Nguyen TH. 2000. Bioclimatic diagrams of Vietnam. Hanoi.

Peel MC, Finlayson BL, McMahon TA. 2007. Updated world map of the Köppen-Geiger climate classification. Hydrology and Earth System Sciences 11: 1633-1644 DOI 10.5194/hess-111633-2007.

Pilgrim JD, Tu ND. 2007. Background paper on threatened and alien species in Vietnam and recommendations for the content of the Biodiversity Law. Report to the Department of Environment, Ministry of Natural Resources and Environment. BirdLife International Vietnam Programme, Hanoi.

Robinson CB. 1910. Philippine Urticaceae. Philippine Journal of Science C. Botany 5: 465-542. Schroeter H, Winkler H. 1935. Monographie der Gattung Elatostema s.l.: Allgemeiner Teil. 
406

407

408

409

410

411

412

413

414

415

416

417

418

419

420

421

422

423

424

425

426

427

Repertorium Specierum Novarum Regni Vegetabilis 83: 1-71.

Schroeter H, Winkle H. 1936. Monographie der Gattung Elatostema s.l.: Spezieller Teil. Repertorium Specierum Novarum Regni Vegetabilis 1936: 1-237.

Seregin A. (Ed.) 2018. Moscow University Herbarium (MW). Version 1.14. https://doi.org/10.15468/cpnhcc.

Shao Q, Lin Q, Duan LD. 2004. A new synonym of Pellionia radicans (Urticaceae). Acta Phytotaxaonomica Sinica 42: 571-572.

Takhtajan A. 1978. The floristic regions of the world. Nauka, Leningrad.

Takhtajan A. 1986. Floristic Regions of the World. University of California Press, Berkeley, Los Angeles, London.

The JSTOR Global Plants portal. Elatostema \& Pellionia. Available at http://plants.jstor.org/ (accessed 30 May 2017)

The Plant List. 2018. Version 1.1. Available from: http://www.theplantlist.org/ (accessed: 6 April 2018).

Tseng YH, Monro AK, Wei YG, Hu JM. in press. Molecular phylogeny and morphology of Elatostema s.l. (Urticaceae): implications for inter- and infrageneric classification. Molecular Phylogenetics and Evolution.

Wang WT. 1980. Classificatio specierum Sinicarum Elatostematis (Urticaceae). Bulletin of Botanical Laboratory of North-Eastern Forestry Institute 7: 40-41, 49-50.

Wang WT. 1983. Notulae de Pellionia Elatostemateque (Urticaceae). Bulletin of Botanical Research 3: 56-66.

Wang WT. 1993. Four new species of Elatostema (Urticaceae) from China. Acta Phytotaxonomica Sinica 31: 170-175.

Wang WT. 2014. Elatostema (Urticaceae) in China.Qingdao Publishing House Qingdao.

Wang WT. 2016. Nova classification specierum sinensium Pellioniae (Urticaceae). Guihaia 36: $1-29$.

Wang WT, Chen CJ. 1995. Pellionia \& Elatostema. In: Wang, W.T. \& Chen, C.J. (Eds.) Flora 
Reipublicae Popularis Sinicae 23. Science Press, Beijing, 160-317.

434 Wei YG, Wang WT. 2009. Notes on Elatostema J. R. et G. Forst. (Urticaceae) from Guangxi. $435 \quad$ Guihaia 29: 711-718.

436

Wei YG, Monro AK, Wang WT. 2011. Additions to the Flora of China: seven new species of Elatostema (Urticaceae) from the karst landscapes of Guangxi and Yunnan. Phytotaxa 29:127 DOI 10.11646/phytotaxa.29.1.1.

Yahara T. 1984. Pellionia and Elatostema in Thailand. Taxonomic studies of Urticaceae II. Journal of the Faculty of Science of the University of Tokyo III 13:483-499.

Zhu H. 2017. Tropical flora of southern China. Biodiversity Science 25: 204-217 DOI 10.17520/biods.2016055.

Zhu H, Yan LC, Qin HN. 2003. Floristic composition and characteristics of Vietnamese flora. Acta Scientiarum Naturalium Universitatis Sunyatseni 42: 98-102.

Table 1. The species richness, endemism, and new records identified per Floristic Region

Figure caption:

Figure 1. Climate map of Vietnam (original, based on Nguyen et al. 2000).

Figure 2. Map of floristic regions in Vietnam. (original, first published by Averyanov et al. 2003c, with modifications).

Figure 3. Plate I of representative Elatostema species in Vietnam: A, E. crassiusculum; B, E. glochidioides; C, E. hookerianum; D, E. prunifolium; E, E. arcuatobracteatum; F, E. retrohirtum; G, E. obtusum; H, E. ramosum; I, E. integrifolium; J, E. fengshanense; K, E. austrosinense; L, E. malacotrichum. 
461 Figure 4. Plate II of representative Elatostema species in Vietnam: A, E. heterolobum; B, E. 462 atroviride; C, E. tenuicaudatum; D, E. nasutum; E, E. cyrtandrifolium; F, E. backeri; G, E. 463 veronicoides; H, E. dissectum; I, E. atropurpureum; J, E. paucidentatum; K, E. lineolatum; L, E. 464 xanthophyllum.

465

Figure 5. Plate III of representative Elatostema species in Vietnam: A, E. caulialatum; B, E. radicans; C, E. tsoongii; D, E. sinense; E, E. brevifolium; F, E. macintyrei; G, E. balansae; H, E. myrtillus; I, E. platyphyllum; J, E. petelotii; K, E. longistipulum; L, E. pseudolongipes.

Figure 6.Variation in Elatostema species richness and endemism across provinces of Vietnam (Based on Vietnam location map.svg (by Uwe Dedering)., CC BY-SA 3.0, https://commons.wikimedia.org/w/index.php?curid=17124413). The tones of green indicate number of species per province. The red figures in brackets indicate number of national endemic species recorded for a province where it is non-zero.

Figure 7. Proportion of diversity and endemism and the relationship of the floristic regions (Large circles designate floristic regions. Percentage numbers above the line in the large circles indicate the relative proportion of diversity occurring in a certain region (within Vietnam); percentage numbers below the line indicate the relative proportion of national endemics occurring in a certain region; percentage numbers in the small circles indicate the relative proportion of co-exsisted species occurring in the pairs of region connected by the line and show their relative floristic 482 relationships). 
483

484

485

486

487

488

489

490

491

492

493

494

495

496

497

498

499

500

501

502

503

504

505

506

507

508

509

\section{Appendix. Checklist of Elatostema in Vietnam}

Species are listed in alphabetical order. Basionyms and synonyms are cited on a separate line in alphabetical order. This is followed by the species' global distribution, elevation range within Vietnam and the exsiccatee seen for this study. New records for Vietnam are denoted by an '* next to the name.

Elatostema acuminatum (Poir.) Brongn.

Procris acuminata Poir.

Boehmeria acuminata Pers., Elatostema lowii Stapf., Elatostema membranaceum Hassk., Elatostema membranifolium Kurz., Langeveldia acuminata Gaudich., Ramium acuminatum (Pers.) Kuntze.

Bhutan, China, Indonesia, Malaysia, Myanmar, Nepal, Sikkim, Thailand, Vietnam; 400$1650 \mathrm{~m}$.

Cao Bang Province: Ha Lang District, Dong Loan Municipality, 2246'N 1034ㄴ'E, L. Averyanov et al. CBL603 (LE); Ha Giang Province: Bac Me District, Phieng Luong Municipality, 22³9'29"N 105¹9'35"E, L. Averyanov et al. HAL6540 (LE); Quan Ba District, Can Ty Municipality, $23^{\circ} 04^{\prime} \mathrm{N} 104^{\circ} 59^{\prime} \mathrm{E}$, N.T. Hiep et al. NTH3622 (LE); Vi Xuyen District, Cao Bo Municipality, Tam Ve Village, 22 ${ }^{\circ} 46^{\prime} 18^{\prime \prime} \mathrm{N} 104^{\circ} 49^{\prime} 01^{\prime \prime E}$, D.K. Harder et al. 5615 (K, MO); Ha Noi City: Ba Vi District, Ba Vi National Park, 2104'22"N 105²1'53"E, L.F. Fu et al. VMN_CN35 (IBK, VNMN); Quang Binh Province: Minh Hoa District, Dan Hoa Municipality, $17^{\circ} 45^{\prime} 28^{\prime \prime} \mathrm{N} 105^{\circ} 46^{\prime} 14^{\prime \prime E}$, L. Averyanov et al. HAL12205 (LE), 1746'34"N 10548'56"E, L. Averyanov et al. HAL12548 (LE); Vinh Phuc Province: Tam Dao District, L. Averyanov et al. $L X-V N 864(\mathrm{LE})$.

Elatostema acutidentatum (W.T.Wang) Y.H.Tseng \& A.K.Monro, comb. nov.

Basionym: Pellionia acutidentata W.T.Wang, Bull. Bot. Lab. N.-E. Forest. Inst., Harbin 6: 53. 1980. Type: China. Yunnan, Xichou county, Fadou village, C.W. Wang \& Y. Liu 85536 (holotype: 
510 PE!).

511 China, Vietnam; 1400-1900 m.

512 Cao Bang Province: Nguyen Binh District, Nguyen Binh Municipality, 22 $37^{\circ} \mathrm{N} 105^{\circ} 52^{\prime} \mathrm{E}, L$.

513 Averyanov et al. CBL195 (LE, MO); Lai Chau Province: Than Uyen District, Ho Mit

514 Municipality, $22^{\circ} 06^{\prime} \mathrm{N} 103^{\circ} 52^{\prime} \mathrm{E}$, N.T. Hiep et al. NTH2842 (LE); Lao Cai Province: Sa Pa

515 District, Anon. TV-284 (HN); Van Ban District, 21 ${ }^{\circ} 59^{\prime} 00^{\prime \prime N} 104^{\circ} 02^{\prime} 00^{\prime \prime E}$, L. Averyanov et al.

516 HAL2215 (LE).

517

518

519

520

521

522

523

524

525

526

527

528

529

530

531

532

533

534

535

Elatostema arcuatobracteatum L.F.Fu, V.T.Do \& C.X.He

\section{Elatostema albopilosum W.T.Wang}

a. Elatostema albopilosum var. vicinum L.D.Duan \& Y.Lin

Endemic; 200-400 m.

Bac Kan Province: Cho Don District, Xuan Lac Commune, 22²1'91"N 105³2'95"E, L.Q.

Li et al. 0432 (PE); Tuyen Quang Province: Na Hang District, H.N. Qin et al. 319 (PE).

This variety is very similar to E. albopilosum W.T.Wang var. albopilosum and further study may result in it being treated as a synonym.

Endemic; ca. $500 \mathrm{~m}$.

Ha Giang Province: Bac Me District, Bac Me Nature Reserve, 2245'15"N 105¹3'43"E, L.F. Fu et al.VMN_CN219(IBK, VNMN).

Elatostema atropurpureum Gagnep.

536 Quan Ba District, Tung Vai Municipality, Thang village, 2303'13"N 10451'49"E, L. Averyanov 
537

538

539

540

541

542

543

544

545

546

547

548

549

550

551

552

553

554

555

556

557

558

559

560

561

562

563

VR558 (LE); Lao Cai Province: Sa Pa District, Sino-Vietnam Expedition 336 (IBSC, PE); Van Ban District, Hoang Lien - Van Ban Nature Reserve, L.F. Fu et al. VMN_CN920 (IBK, VNMN); P.A. Petelot 5100 (P); Ninh Binh Province: Nho Quan District, Cuc Phuong National Park, F. Wen et al.VMN_CN600,VMN_CN606(IBK, VNMN); Phu Tho Province: Thanh Son District, Xuan Son Municipality, Xuan Son National Park, $21^{\circ} 08^{\prime} 00^{\prime \prime} N 104^{\circ} 55^{\prime} 55^{\prime \prime}$, M.S. Nuraliev \& N.A. Vislobokov 1105 (IBK, MW).

\section{Elatostema atroviride W.T.Wang}

Elatostema atroviride var. lobulatum W.T.Wang, E. leiocephalum W.T.Wang, E. papilionaceum W.T.Wang. China, Vietnam; 200-1500 m.

Cao Bang Province: Ha Quang District, Pac Bo, L.F. Fu et al. VMN_CN783 (IBK, VNMN); Ha Giang Province: Yen Minh District, Lao Va Chai Municipality, 2307'N 10508'E, N.T. Hiep et al. NTH3448 (LE); Hai Phong City: Cat Hai District, Y.G. Wei et al. VMN_CN14 (IBK, VNMN); Cat Hai District, Cat Ba Island, N. Arnautov et al. LX-VN3626, LX-VN3774, LX-VN3793, $L X-V N 3834$ (LE); between Meo Vac District and Dong Van District, 2315'16"N 105'23'12"E, L.F. Fu et al. VMN_CN190(IBK, VNMN); 2245'23"N 105¹3'46"E, L.F. Fu et al. VMN_CN218 (IBK, VNMN); Hoa Binh Province: Mai Chau District, Pa Co Municipality, 2044'32.3"N 10456'26.9"E, V.X. Phuong et al. HNK639 (K); Nghe An Province: Quy Chau District, Pu Huong Natural Reserve, F. Wen et al. VMN_CN478(IBK, VNMN); Con Cuong District, Cay Da Valley, Truong Huong Hamlet, Yen Khe Commune, 190'39.3"N 10451'38"E, V.D. Nguyen et al. HNK2960 (K); Ninh Binh Province: Nho Quan District, Cuc Phuong National Park, J.M. Hu Hu2 177 (TAI); Quang Binh Province: Minh Hoa District, Thong Hoa Municipality, 1740'N 10557'E, L. Averyanov et al. VH4797 (LE); Tuyen Hoa District, Lam Hoa Municipality, 1755'41"N 10549'43"E, L. Averyanov et al. CPC2620 (LE); Son La Province: Moc Chau District, Van Ho Municipality, Hua Tat Village, 2046'18"N 10447'45"E, D.K. Harder et al. 5774 (HN, K, MO), 2046'18"N 10447'29"E, N.T. Hiep et al. HAL9311 (LE); Thanh Hoa 
564 Province: Quy Chau District, Pu Huong Natural Reserve, F. Wen et al. VMN_CN427 (IBK, 565 VNMN); Thuong Xuan District, Bat Mot Municipality, 2001'12"N 10457'48"E, L. Averyanov et

566

567

568

569

570

571

572

573

574

575

576

577

578

579

580

581

582

583

584

585

586

587

588

589

590

*Elatostema attenuatoides W.T.Wang

China, Vietnam; 500-800 m.

Cao Bang Province: Ha Lang District, An Lac Municipality, $22^{\circ} 43^{\prime} \mathrm{N} 103^{\circ} 36^{\prime} \mathrm{E}, \mathrm{L}$.

Averyanov et al. CBL786 (LE, MO); Tra Linh District, Quoc Toan Municipality, 2245'15"N

$106^{\circ} 17^{\prime} 54 " \mathrm{E}$, D.K. Harder et al. 4336 (K); 2245'30"N 106¹7'22"E, L. Averyanov et al. VH4854

(HN, LE, MO), VH4949 (LE, MO); 2245'N 106¹9'E, L. Averyanov et al. CBL1256 (LE, MO).

*Elatostema austrosinense Y.H.Tseng \& A.K.Monro nom. nov.

non E. macrophyllum Brongn.

Pellionia macrophylla W.T.Wang, Acta Bot. Yunnan. 5: 271, 1980. Type: China. Yunnan,

Luchun county, Huanglianshan, D.D. Tao 845 (holotype: KUN!).

China, Vietnam; ca. $1650 \mathrm{~m}$.

Lao Cai Province: Sa Pa District, Hoang Lien National Park, L.F. Fu et al. VMN_CN884

(IBK, VNMN); Van Ban District, 21 ${ }^{\circ} 58^{\prime} 42^{\prime \prime N} 104^{\circ} 00^{\prime} 37^{\prime \prime E}$, L. Averyanov et al. HAL2072,

HAL2088 (LE).

We selected 'austrosinense' as epiphet as it coincides with the origin of its distribution area, South China.

Elatostema backanense (Gagnep.) Y.H.Tseng \& A.K.Monro, comb. nov.

Basionym: Pellionia backanensis Gagnep., Bull. Soc. Bot. France 75: 918. 1928. Type:

Vietnam. Bac Kan, Yen Lac District, P.A. Eberhardt 4669 (holotype: P!).

Endemic; elevation unknown.

Bac Kan Province: Yen Lac District, P.A. Eberhardt 4669 (P). 
592

593

594

595

596

597

598

599

600

601

602

603

604

605

606

607

608

609

610

611

612

613

614

615

616

617

*Elatostema backeri H.Schroet.

China, Indonesia, Vietnam; elevation unknown.

Cao Bang Province: Bao Lac District, Dinh Phung Municipality, L.F. Fu et al. VMN_CN814

(IBK, VNMN); Bao Lam District, Tan Viet, Na Dang, L.F. Fu et al. VMN_CN829 (IBK, VNMN);

Thanh Hoa Province: Quan Hua District, Pu Luong Nature Reserve. F. Wen et al. VMN_CN551 (IBK, VNMN).

\section{Elatostema balansae Gagnep.}

Elatostema balansae var. hispidum W.T.Wang, E. platyphyllum Wedd. var. balansae (Gagnep.) Yahara.

China, Malaysia, Thailand, Vietnam; 1100-1700 m.

Cao Bang Province: Nguyen Binh District, Phia Oac - Phia Den Nature Reserve, 2237'49"N 10553'11"E, L.F. Fu et al. VMN_CN170 (IBK, VNMN); Ha Giang Province:

between Meo Vac District and Dong Van District, 2309'16"N 105²4'52"E, L.F. Fu et al.

VMN_CN192 (IBK, VNMN); Hoa Binh Province: Mai Chau District, Hang Kia Municipality, 2043'39"N 10453'43"E, N.T. Hiep et al. HAL751 (HN); Lai Chau Province: Sin Ho District, Ta Ngau Municipality, $22^{\circ} 18^{\prime} \mathrm{N} 103^{\circ} 15^{\prime} \mathrm{E}$, N.T. Hiep et al. NTH2783 (LE); Lam Dong Province: Lac Duong District, Da Chais Municipality, $12^{\circ} 08^{\prime} \mathrm{N} 108^{\circ} 39^{\prime} \mathrm{E}$, L. Averyanov et al. VH45 11 (LE, MO); Lac Duong District, Da Chais Municipality, Bi Doup mountains, 12¹1'07.0"N 10842'55.9"E, A.N. Demidova \& N.G. Prilepsky 431 (MW); Son La Province, Yen Chau District, Muong Lum Municipality, On Oc Village, 2059'44"N 104³0'03"E, D.K. Harder et al. 7229 (HN).

Elatostema brachyodontum (Hand.-Mazz.) W.T.Wang Elatostema ficoides Wedd. var. brachyodontum Hand.-Mazz. China, Vietnam; elevation unknown. Province unknown: Phuong-Lam, B. Balansa 2535 (P). 
*Elatostema brunneinerve W.T.Wang

China, Vietnam; 1200-1400 m.

Ha Giang province: Quan Ba District, Tung Vai Municipality, Thang village, $23^{\circ} 03^{\prime} 42^{\prime \prime} \mathrm{N}$ $104^{\circ} 50^{\prime} 42^{\prime \prime} \mathrm{E}$, L. Averyanov et al. VR591 (LE).

Elatostema caulialatum (S.Y.Liou) Y.H.Tseng \& A.K.Monro, comb. nov.

Basionym: Pellionia caulialata S.Y.Liou, Guihaia 3(4): 317. 1983. Type: China. Guangxi, Guiping County, Dapingshan, S.Y. Liu et al. D00322 (holotype: GXMI!, isotypes: PE!). China, Vietnam; 200-415 m.

Bac Kan Province: Cho Don District, Xuan Lac Community, 22²1.91'N 105³2.95'E, L.Q. Li et al. $0386(\mathrm{HN})$; Na Ri District, Kim Hy Nature Reserve, 22 17'54"N 10601'40"E, L.F. Fu et al.VMN_CN128(IBK, VNMN); Ha Giang Province: Meo Vac District, L.F. Fu et al. VMN_CN859(IBK, VNMN); Thai Nguyen Province: Vo Nhai District, Truong Lung Municipality, $21^{\circ} 48.75^{\prime} \mathrm{N} 105^{\circ} 58.09^{\prime} \mathrm{E}$, L.Q. Li et al. 0142 (HN); Tuyen Quang Province: Na Hang District, Anon. TV-93 (HN). 
645

646 Elatostema chapaense (Gagnep.) Y.H.Tseng \& A.K.Monro, comb. nov.

647 Basionym: Pellionia chapaensis Gagnep., Bull. Soc. Bot. France 75: 920. 1928. Type:

648 Vietnam. Lao Cai, Sa Pa District, H. Lecomte \& A. Finet 415 (holotype: P!).

649 Endemic; elevation unknown.

650 Lao Cai Province: Sa Pa District, H. Lecomte \& A. Finet 415 (P).

651

Elatostema cochinchinense (Gagnep.) Y.H.Tseng \& A.K.Monro, comb. nov.

654

655

656

657

658

659

660

661

662

663

664

665

666

667

668

669

670

671
Basionym: Pellionia cochinchinensis Gagnep., Bull. Soc. Bot. France 75: 921. 1928. Type:

Vietnam. Haut Donnai, Con-heu Mountain, L. Pierre 4814 (holotype: A!).

Endemic; elevation unknown.

Province unknown: Haut Donnai, Con-heu Mountain, L. Pierre 4814 (A).

*Elatostema crassiusculum W.T.Wang

China, Vietnam; ca. $200 \mathrm{~m}$.

Cao Bang Province: Bao Lam District, Nam Quang, L.F. Fu et al. VMN_CN838 (IBK, VNMN).

*Elatostema crenatum W.T.Wang.

China, Vietnam, elevation unknown.

Phu Tho Province: Ha Ho District, Ao Chau, V.X. Phuong 3483 (HN).

Elatostema crispulihirtellum (W.T.Wang) Y.H.Tseng \& A.K.Monro, comb. nov.

Basionym: Pellionia crispulihirtella W.T.Wang, Bull. Bot. Res., Harbin 3(3): 57. 1983. Type:

China. Yunnan, Pingbian, Shantou county, C.W. Wang 82383 (holotype: PE!). China, Vietnam; $710 \mathrm{~m}$.

Lao Cai Province: On the way from Lao Cai to Sa Pa, Sino-Vietnam Expedition 856 (PE). 
Elatostema cyrtandrifolium (Zoll. \& Mor.) Miq.

$674 \quad$ Procris cyrtandrifolia Zoll. \& Mor.

Elatostema herbaceifolium Hayata, E. sessile var. cyrtandrifolium (Zoll. \& Mor.) Wedd., E. sessile var. pubescens Hook.f., E. herbaceifolium Hayata.

Bhutan, China, India, Indonesia, Malaysia, Myanmar, Thailand, Vietnam; 200-1050 m.

Cao Bang Province: Tra Linh District, Luu Ngoc Municipality, $22^{\circ} 47^{\prime} \mathrm{N} 106^{\circ} 18^{\prime} \mathrm{E}, \mathrm{L}$.

Averyanov et al. CBL1203 (LE, MO); Dien Bien Province: Tua Chua District, Xa Nhe

Municipality, 21 $52^{\prime} 35^{\prime \prime N} 103^{\circ} 24^{\prime} 21^{\prime \prime E}$, L. Averyanov et al. CPC2221 (LE); Ha Giang Province: between Meo Vac District and Dong Van District, 2313'45"N 105²4'48"E, L.F. Fu et al.

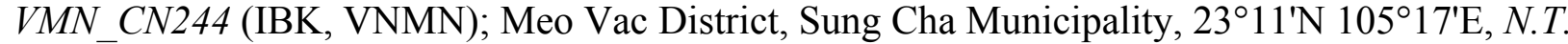

Hiep et al. NTH3302 (LE); Hai Phong City: Cat Hai District, Cat Ba Island, N. Arnautov et al. LXVN3796 (LE); Ninh Binh Province: Nho Quan District, Cuc Phuong National Park, J.M. Hu Hu2 187 (TAI); Quang Binh Province: Minh Hoa District, Thong Hoa Municipality, 1740'N 10557'E, L. Averyanov et al. VH4611 (LE), VH4793 (HN, LE, MO); Son La Province: Moc Chau District, Chieng Hac Municipality, 2051'N 104³8'E, N.T. Hiep et al. NTH2937 (LE);

Thanh Hoa Province, Quy Chau District, Pu Huong Natural Reserve, F. Wen et al. VMN_CN421 (IBK, VNMN).

Elatostema dissectum Wedd., Arch. Mus. Hist. Nat. 9(1-2): 314. 1856. Type: India, Khasia, D. Hooker \& T. Thomson s.n. (lectotype: designated by Lin, Duan \& Yang, 2009: 1910, P!). Elatostema paragungshanense W.T.Wang, Pellionia tonkinensis Gagnep. Pellionia tetramera Gagnep., Bull. Soc. Bot. France 75: 925. 1928, syn. nov. Type: Vietnam. Ba Vi District, Ba Vi Mountain, B. Balansa 2536 (holotype: P!). Bhutan, China, India, Laos, Sikkim, Thailand, Vietnam; 200-1350 m.

Bac Kan Province: Phu Thong Hoa, P.A. Eberharadt 4724 (P); Ha Noi City: Ba Vi District, Ba Vi National Park, V.D. Nguyen et al. HNK 1268 (K); Ba Vi District, Ba Vi Mountain, B. 
699

700

701

702

703

704

705

706

707

708

709

710

711

712

713

714

715

716

717

718

719

720

721

722

723

724

725

Balansa 2536 (P); Ha Giang province: Quan Ba District, Tung Vai Municipality, Thang village, $23^{\circ} 03^{\prime} 13^{\prime \prime} \mathrm{N} 104^{\circ} 51^{\prime} 49^{\prime \prime} \mathrm{E}$, L. Averyanov et al. VR554, VR559, VR563, VR660, VR713 (LE); Hoa

Binh Province: Da Bac District, Cao Son Municipality, Buoi Truong Station, 2052'31"N 105'11'48"E, N.T. Hiep et al. HAL540 (HN, MO); Mai Chau District, F. Wen et al. VMN_CN262 (IBK, VNMN); Mai Chou District, Hang Kia-Pa Co Nature Reserve, F. Wen et al. VMN_CN326, VMN_CN331,VMN_CN337(IBK, VNMN); Kon Tum Province: Dak Glei District, L. Averyanov et al. VH1757 (HN, MO); Lang Son Province: Bac Son District, Tan Tri Municipality, L. Averyanov et al. HAL6783 (LE); Lao Cai Province: Sa Pa District, Hoang Lien National Park, Ton Forest Station, L.F. Fu et al. VMN_CN916 (IBK, VNMN); Van Ban District, Khanh Yen Ha Municipality, to the S of Na Nheo Village, 21 ${ }^{\circ} 59^{\prime} 04^{\prime \prime} \mathrm{N} 104^{\circ} 15^{\prime} 08^{\prime \prime} \mathrm{E}$, L. Averyanov et al. HAL 2814 (HN, LE); Van Ban District, Nam Xe Municipality, 22 $011^{\prime 2} 7^{\prime \prime N} 104^{\circ} 00^{\prime} 25^{\prime \prime E}$, D.K. Harder et al. DKH7051 (LE); Nghe An Province: Con Cuong District, Chau Khe Municipality, Pu Mat National Park, 1855'56"N 104³5'01"E, M.S. Nuarliev 2128 (MW); Quy Chau District, Pu Huong Natural Reserve, F. Wen et al. VMN_CN486 (IBK, VNMN); Tuong Duong District, Tam Hop

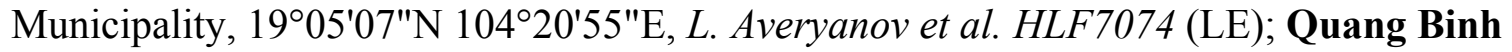

Province: Minh Hoa District, Dan Hoa Municipality, 1741'50"N 10545'54"E, L. Averyanovet al. HAL12410 (LE); Quang Tri Province: Huong Hoa District, Huong Viet Municipality, 1651'14"N 106³4'13"E, N.T. Hiep et al. HLF5947 (LE); Son La Province: Chieng Yen District, N.H. Hien et al. VN239 (HN); Tuyen Quang Province: Bach Ngoc, P.A. Eberhardt $4818(\mathrm{P})$; Na Hang District, Vinh Yen Municipality, 22²1'09"N 105²5'20"E, L.V. Cham et al. HLF299 (HN).

We place Pellionia tetramera in synonymy based on its shared characters with Elatostema dissectum: oblong-lanceolate lamina and staminate inflorescence with long peduncle.

Elatostema eberhardtii (Gagnep.) Y.H.Tseng \& A.K.Monro, comb. nov.

Basionym: Pellionia eberhardtii Gagnep., Bull. Soc. Bot. France 75: 921. 1928. Type:

Vietnam. Quang Tri, Cu Bi, P.A. Eberharadt 1962 (holotype: P!).

Endemic; elevation unknown. 
Quang Tri Province: Cu Bi, P.A. Eberharadt 1962 (P).

727

728

729

730

731

732

733

734

735

736

737

738

739

740

741

742

743

744

745

746

747

748

749

750

751

752

Elatostema eurhynchum Miq. Indonesia, Vietnam; $1600 \mathrm{~m}$.

Kon Tum Province: Dak Glei District, 1504'00"N 10759'00"E, L. Averyanov et al. VH797 (HN, LE, MO).

\section{*Elatostema fengshanense W.T.Wang \& Y.G.Wei} China, Vietnam; elevation unknown. Cao Bang Province: Ha Quang District, Pac Bo, L.F. Fu et al. VMN_CN786 (IBK, VNMN).

Elatostema ficoides Wedd. Elatostema mariannae C.B.Clarke. China, India, Nepal, Sikkim, Vietnam; $400 \mathrm{~m}$.

Bac Kan Province: Na Ri District, Kim Hy Nature Reserve, 22 $11^{\prime} 56^{\prime \prime} \mathrm{N} 106^{\circ} 04^{\prime} 04^{\prime \prime} \mathrm{E}$, L.F. Fu et al. VMN_CN129(IBK, VNMN). Hoa Binh Province: Crieng Xen, P.A. Petelot 2965 (P).

\section{*Elatostema glochidioides W.T.Wang} China, Vietnam; 300-1190 m.

Ha Giang Province: Between Meo Vac District and Dong Van District, L.F. Fu et al. $V M N \_C N 233$ (IBK, VNMN); Quan Ba District, Bat Dai Son Nature Reserve, Thanh Van commune, Mo Sai village, 2307'46"N 10457'56"E, L. Averyanov et al. VR417 (LE); Quan Ba District, Thang village, $23^{\circ} 03^{\prime} 13^{\prime \prime N} 104^{\circ} 51^{\prime} 49^{\prime \prime} \mathrm{E}$ L. Averyanov et al. VR553 (LE).

Elatostema grijsii (Hance) Y.H.Tseng \& A.K.Monro, comb. nov. Basionym: Pellionia grijsii Hance, J. Bot. 6(62): 49. 1868. Type: China. Fujian, Exsicc. 6704 (holotype: BM!). 


\section{Pellionia funingensis W.T.Wang.}

China, Vietnam; 800-1900 m.

Cao Bang Province: Nguyen Binh District, Nguyen Binh Municipality, $22^{\circ} 37^{\prime} \mathrm{N} 105^{\circ} 52^{\prime} \mathrm{E}, L$. Averyanov et al. CBL069 (LE, MO); Nguyen Binh District, Phia Oac - Phia Den Nature Reserve, 2236'24"N 105'52'46"E, L.F. Fu et al. VMN_CN157 (IBK, VNMN); Lang Son Province: Bac Son District, Tan Tri Municipality, L. Averyanov et al. HAL6753 (LE); Lao Cai Province: Van Ban District, Hoang Lien - Van Ban Nature Reserve, L.F. Fu et al. VMN_CN921 (IBK, VNMN); Vinh Phuc Province: Tam Dao Range, N. Arnautov et al. LX-VN4004 (LE).

Elatostema heterolobum (Wedd.) Hallier f.

Pellionia heteroloba Wedd.

Elatostema bicuspidatum Hallier f., E. griffithianum (Wedd.) Hallier f., E. henryanum Hand.Mazz., Pellionia heteroloba var. minor W.T.Wang, P. keitaoensis Yamam., P. menglianensis Y.Y.Qian.

Bhutan, China, India, Laos, Myanmar, Sikkim, Vietnam; 400-1900 m.

Cao Bang Province: Bao Lac District, Dinh Phung Municipality, L.F. Fu et al. VMN_CN816 (IBK, VNMN); Nguyen Binh District, Nguyen Binh Municipality, 22³7'N 10552'E, L. Averyanov et al. CBL035, CBL062 (HN, LE, MO); Ha Giang Province: Meo Vac District, Vicinities of Meo Vac Town, 2310'N 105²4'E, N.T. Hiep et al. NTH3385 (LE); Quan Ba District, Tung Vai Municipality, L.F. Fu et al. VMN_CN870 (IBK, VNMN); Ha Noi City: Ba Vi District, Ba Vi National Park, V.D. Nguyen et al. HNK1266 (K); Hoa Binh Province: Mai Chau District, Pa Co Municipality, V.X. Phuong 2397 (HN); Lao Cai Province: Sa Pa District, B. Khao \& V. Trung 2545 (HN); Van Ban District, Khanh Yen Ha Municipality, 2158'28"N 104²15'52"E, L. Averyanov et al. HAL2312 (LE, MO); Nghe An Province: Con Cuong District, Chau Khe Municipality, Pu Mat National Park, 1855'51"N 104³6'20"E, M.S. Nuarliev et al. 2042 (MW); Quang Binh Province: Minh Hoa District, Dan Hoa Municipality, 1741'50"N 10545'54"E, L. Averyanov et al. HAL12250, HAL12412 (LE); Son La Province: Van Ho District, Tan Xuan 
Municipality, 2040'33"N 104³9'00"E, L. Averyanov et al. CPC7127 (LE).

Elatostema heyneanum (Wedd.) Hallier f. Pellionia heyneana Wedd. Cambodia, China, India, Indonesia, Sri Lanka, Thailand, Vietnam; 100-300 m. Ha Noi City: Ba Vi District, Ba Vi Mountain, B. Balansa 2549 (P); Quang Binh Province: Tuyen Hoa District, Lam Hoa Municipality, 1756'51"N 10549'18"E, L. Averyanov et al. CPC2679, CPC2696(LE); Quang Tri Province: Da Krong District, Ta Rut Municipality, $16^{\circ} 24^{\prime} 29^{\prime \prime} \mathrm{N} 107^{\circ} 01^{\prime} 07^{\prime \prime E}$, L. Averyanov et al. CPC3049(LE).

Elatostema hookerianum Wedd., Arch. Mus. Hist. Nat. 9(1-2): 309. 1856, Type: Sikkim, J.D. Hooker s.n. (holotype: P!, isotype: MPU!).

Elatostema subfalcatum W.T.Wang.

Pellionia macroceras Gagnep., Bull. Soc. Bot. France 75: 922. 1928, syn. nov. Type:

Vietnam. Lao Cai, Sa Pa District, P.A. Petelot 2294 (lectotype: P: P00601742!, designated here, isolectotype: P: P00601741!).

Bhutan, China, India, Sikkim, Vietnam; 1200-2100 m.

Lai Chau Province: Than Uyen District, Ho Mit Municipality, $22^{\circ} 06^{\prime} \mathrm{N} 103^{\circ} 52^{\prime} \mathrm{E}$, N.T. Hiep et al. NTH2668, NTH2809, NTH2832, NTH2874 (LE); Lao Cai Province: Sa Pa District, Hoang Lien Natinal Park, L.F. Fu et al. VMN_CN882 (IBK, VNMN), P.A. Petelot 2294 (P); Son La Province: Yen Chau District, Muong Lum Municipality, Lum Village, 2100'17"N 104²9'08"E, D.K. Harder et al. 7217 (HN); Province unknown (Northern Vietnam): G.V. Mikeshin s.n. (MHA).

Note: The protologue of Pellionia macroceras (Gagnepain, 1928) includes a description of the species with two type localities of 'Chapa' (Vietnam) and Sikkim. The former relates to the collection P.A. Petelot 2294 with two duplicates housed at P (barcodes P00601741, P00601742), while the latter is represented by the collection $J$. de Rémy 1863 with a single specimen at $\mathrm{P}$ 
807 (barcode P00601743). All of these specimens contain the name 'Pellionia macroceras Gagnep.'

808

809

810

811

812

written in Gagnapain's handwriting and match the protologue description well. The dates of these collections (1925 and 1863) are before the publication of the protologue (1928), and therefore were used during its preparation. We select the specimen P.A. Petelot 2294 (P: P00601742) as the lectotype because it contains anatomical drawing with short notes made by Gagnepain; the other one (P: P00601741) is isolectotype. The status of the specimen J. de Rémy 1863 (P: P00601743) can be indicated as a remaining syntype.

We place Pellionia macroceras in synonymy based on the same characters of falcate lamina with cordate base with Elatostema hookerianum.

Elatostema integrifolium (D.Don) Wedd. Procris integrifolia D.Don. Elatostema cuspidiferum Miq., E. miquelianum Wedd., E. pulgarense Elmer, E. sesquifolium (Reinw. ex Blume) Hassk., E. sesquifolium var. integrifolium (D.Don) Wedd., E. viridicaule W.T.Wang, E. zollingerianum Wedd., Procris sesquifolia Reinw. ex Blume. Bhutan, China, India, Indonesia, Myanmar, Nepal, Thailand, Vietnam; 600-900 m. Cao Bang Province: Bao Lac District, Dinh Phung Municipality, L.F. Fu et al. VMN_CN819 (IBK, VNMN); Hai Phong City: Cat Hai District, Y.G. Wei et al. VMN_CNO6 (IBK, VNMN); Cat Hai District, Cat Ba Island, N. Arnautov et al. $L X-V N 3778$ (LE); Hoa Binh Province: Lac Son District, Tu Do Municipality, 20²5'29"N 105¹9'36"E, N.Q. Hieu et al. CPC1538(LE); Kon Tum Province: Sa Thay District, Ro Koi Municipality, Chu Mom Ray National Park, 14²8'20"N 10743'00"E, M.S. Nuraliev \& S.P. Kuznetsova 1257 (IBK, MW); Lam Dong Province: Bao Loc District, L. Averyanov et al. III-LX-VN1183(LE); Quang Tri Province: Da Krong District, Ta Rut Municipality, 16²4'29"N 10701'07"E, L. Averyanov et al. CPC3039 (LE); Huong Hoa District, Huong Viet Municipality, 1651'06"N 106³4'38"E, L. Averyanov et al. CPC2815 (LE).

Elatostema kimhyense Y.G.Wei \& V.T.Do 
834

835

836

837

838

839

840

841

842

843

844

845

846

847

848

849

850

851

852

853

854

855

856

857

858

859

860

Endemic; 350-1200 m.

Bac Kan Province: Na Ri District, Kim Hy National Park, 22 ${ }^{\circ} 11^{\prime} 56^{\prime \prime} \mathrm{N} 106^{\circ} 4^{\prime} 5^{\prime \prime} \mathrm{E}$, Y.G. Wei \& V.T. Do V-23 (IBK, PE, VNMN), L.F. Fu et al. VMN_CN194 (IBK, VNMN).

\section{Elatostema laevissimum W.T.Wang}

Elatostema laevissimum W.T.Wang var. puberulum W.T.Wang. China, Vietnam; 780-2200 m.

Ha Giang Province: Meo Vac District, Vicinities of Meo Vac Town, $23^{\circ} 10^{\prime} \mathrm{N} 105^{\circ} 24^{\prime} \mathrm{E}$, N.T. Hiep et al. NTH3378, NTH3390 (LE); Quan Ba District, Tung Vai, L.F. Fu et al. VMN_CN871 (IBK, VNMN); between Meo Vac District and Dong Van District, 2307'31"N 105²5'42"E, L.F. Fu et al. VMN_CN188(IBK, VNMN); Kon Tum Province: Dak Glei District, 1504'23"N $108^{\circ} 01^{\prime} 34^{\prime \prime E}$, L. Averyanov et al. VH062 (HN, MO), 1504'00"N 10759'00"E, L. Averyanov et al. VH629 (HN, LE, MO), VH074, VH590 (LE, MO); Lai Chau Province: Than Uyen District, Ho Mit Municipality, $22^{\circ} 06^{\prime} \mathrm{N} 103^{\circ} 52^{\prime} \mathrm{E}$, N.T. Hiep et al. NTH2812 (LE); Lao Cai Province: Van Ban

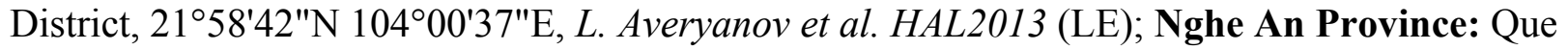
Phong District, Hanh Dich Municipality, Pu Hoat Nature Reserve, 1944'15"N 10448'59"E, M.S. Nuraliev 2192 (MW); Quang Nam Province: L. Averyanov et al. VH923 (LE).

Elatostema leiocarpum (W.T.Wang) Y.H.Tseng \& A.K.Monro, comb. nov. Basionym: Pellionia leiocarpa W.T.Wang, Guihaia 2(3): 115. 1982. Type: China. Guangxi, Napo, Baidu, Nunghua, D. Fang et al. 25142 (holotype: GXMI!).

China, Vietnam; ca. $1200 \mathrm{~m}$.

Ha Giang Province: Quan Ba District, Bat Dai Son Nature Reserve, 2309'18"N 10500'09"E, D.K. Harder et al. 5029 (HN); Quan Ba District, Can Ty Municipality, 2304'N $104^{\circ} 59^{\prime} \mathrm{E}$, N.T. Hiep et al. NTH3618 (LE); Quan Ba District, San Chu village, 230'ㄷㄴNN 10459'46"E, L. Averyanov et al. VR079 (LE); Quan Ba District, Tung Vai Municipality, Thang village, $23^{\circ} 03^{\prime} 41^{\prime \prime} \mathrm{N} 104^{\circ} 50^{\prime} 42^{\prime \prime} \mathrm{E}$, L. Averyanov et al. VR575 (LE). 
Elatostema lineolatum Wight

Elatostema lineolatum var. majus Wedd., E. tumidulum Koidz. Bhutan, China, India, Myanmar, Nepal, Sikkim, Sri Lanka, Thailand; 150-1300 m.

Cao Bang Province: Bao Lac District, Xuan Truong Municipality, L.F. Fu et al.

VMN_CN809 (IBK, VNMN); Nguyen Binh District, Phia Oac - Phia Den Nature Reserve, 22 37'40"N 10553'10"E, L.F. Fu et al. VMN_CN163 (IBK, VNMN); Dak Lak Province: Lak

District, Bong Krang Municipality, Chu Yang Sin National Park, 12²5'00"N 108²3'00"E, M.S.

Nuraliev et al. 925 (K, MW); Ha Giang Province: Bac Me District, Bac Me Nature Reserve, L.F.

Fu et al. VMN_CN232(IBK, VNMN); Gia Lai Province: K'Bang District, Son Lang Municipality,

Kon Chu Rang Nature Reserve, 14³0'55"N 108³2'48"E, M.S. Nuraliev 2010 (MW), 14³0'59"N

108³2'27"E, M.S. Nuraliev 2020 (MW); Lang Son Province: Bac Son District, Tan Tri

Municipality, L. Averyanov et al. HAL6787 (LE); Lao Cai Province: Sa Pa District, San Sa Ho

Municipality, Hoang lien National Park, Cat Cat village area, $22^{\circ} 20^{\prime} \mathrm{N} 103^{\circ} 49^{\prime} \mathrm{E}$, M.S. Nuraliev \&

D.D. Sokoloff 282 (MW); Van Ban District, Nam Xe Municipality, 2202'35"N 10357'23"E, D.K.

Harder et al. 7010 (HN, LE); Nghe An Province: Con Cuong District, Chau Khe Municipality, Pu

Mat National Park, 1857'38"N 10440'44"E, M.S. Nuraliev 2065 (MW); Tuong Duong District,

Tam Quang Municipality, 1903'09"N 104³6'53"E, L. Averyanov et al. HLF6758 (LE); Quang

Binh Province: Bo Trach District, Hung Trach Municipality, 17²7'30"N 106 23'06"E, S.K. Wu

et al. WP923 (HN); Vinh Phuc Province: N. Arnautov et al. LX-VN3985 (LE); Tam Dao District, $21^{\circ} 28^{\prime} 02^{\prime \prime} \mathrm{N} 105^{\circ} 38^{\prime} 39^{\prime \prime E}, L . F . F u$ et al. VMN_CN51 (IBK, VNMN).

Elatostema longibracteatum W.T.Wang

\section{a. Elatostema longibracteatum var. glabricaule W.T.Wang}

Endemic; 650-800 m.

Cao Bang Province: Tra Linh District, Quoc Toan Municipality, L. Averyanov et al. VH2468 (HN, LE); 2245'25"N 106¹7'58"E, D.K. Harder et al. 4288 (K); Tra Linh District, Luu Ngoc 
Municipality, $22^{\circ} 47^{\prime} \mathrm{N} 106^{\circ} 18^{\prime} \mathrm{E}, L$. Averyanov et al. CBL1199 (LE, MO).

This variety is very similar to Elatostema longibracteatum W.T.Wang var. longibracteatum and further study may result in it being treated as a synonym.

Elatostema longipedunculatum (W.T.Wang) Y.H.Tseng \& A.K.Monro, comb. nov.

Basionym: Pellionia longipedunculata W.T.Wang, Bull. Bot. Res., Harbin 2(1): 1. 1982.

Type: China. Guangxi, Shangsi County, Shiwandashan, S.C. Chen 4918 (holotype: IBSC!).

Pellionia subundulata W.T.Wang var. angustifolia W.T. Wang.

China, Vietnam; 197-1000 m.

Ha Noi City: Ba Vi District, Ba Vi Mountain, $21^{\circ} 04.096^{\prime} \mathrm{N} 105^{\circ} 21.501^{\prime} \mathrm{E}$, N.A. Vislobokov \& S.P. Kuznetsova 681 (MW); Ha Tinh Province: Huong Son District, Rao An-Ngam Thep village, 18²1'53"N 105¹3'12"E, T.H. Nguyen et al. 184 (MO); Vinh Phuc Province: Tam Dao District, Sino-Vietnam Expedition 1996 A (PE).

\section{Elatostema longistipulum Hand.-Mazz.}

China, Vietnam; 140-1450 m.

Cao Bang Province: Ha Lang District, Thang Loi Municipality, $22^{\circ} 45^{\prime} \mathrm{N} 106^{\circ} 42^{\prime} \mathrm{E}$, P.K. Loc et al. CBL1661 (LE, MO); Ha Giang Province: Bac Me District, Bac Me Nature Reserve, 2238'37"N 105²8'36"E, L.F. Fu et al. VMN_CN220 (IBK, VNMN); Ha Noi City: Ba Vi District, Ba Vi National Park, V.D. Nguyen et al. HNK1282 (K); Hoa Binh Province: Lac Son District, Tu Do Municipality, 20²4'57"N 105¹3'16"E, N.Q. Hieu et al. CPC1403 (LE); Mai Chau District, F. Wen et al.VMN_CN274, VMN_CN274,VMN_CN317,VMN_CN323 (IBK, VNMN); Lang Son Province: Huu Lung District, Huu Lien Municipality, 21 40'59"N 106²0'30"E, D.K. Harder 4116 (MO); Nghe An Province: Con Cuong District, Chau Khe Municipality, Pu Mat National Park, 1857'42"N 10441'40"E, M.S. Nuraliev 2077 (MW); Quy Hop District, Chau Thai Municipality, Bom Village, V.D. Nguyen et al. HNK1611(K); Ninh Binh Province: Nho Quan 
915 District, Cuc Phuong National Park, J.M. Hu Hu2110 (TAI); L. Averyanov et al. LX-VN1732 (LE), 916 V.D. Nguyen et al. HNK1334 (K); Phu Tho Province: Tan Son District, Xuan Son Municipality, $91721^{\circ} 02^{\prime} 55^{\prime \prime} \mathrm{N} 104^{\circ} 56^{\prime} 51^{\prime \prime E}, L$. Averyanov et al. HAL12722 (LE), 2106'57"N 10457'17"E, L. 918 Averyanov et al. HAL12677 (LE); Quang Binh Province: G.V. Mikeshin, O.V. Daeva s.n. (MHA); 919 Son La Province: Van Ho District, Tan Xuan Municipality, 2040'33"N 104³9'00"E, L. 920 Averyanov et al. CPC7143 (LE); Yen Chau District, Muong Lum Municipality, 2100'35"N 921 104²9'06"E, L. Averyanov et al. CPC1884 (LE); Thai Nguyen Province: Vo Nhai District, Than 922 Sa Municipality, $21^{\circ} 48^{\prime}$ N 10554'E, N.T. Hiep et al. NTH3780 (LE); Thanh Hoa Province: Quy 923 Chau District, Pu Huong Natural Reserve, F. Wen et al. VMN_CN428(IBK, VNMN); Quan Hoa 924 District, Hien Chung Municipality, Xuan Lien Reserve, F. Wen et al.VMN_CN398,VMN_CN410 925 (IBK, VNMN); Quan Hoa District, Pu Hu Nature Reserve; F. Wen et al. VMN_CN350 (IBK, 926 VNMN); Thuong Xuan District, Bat Mot Municipality, 1959'11"N 10458'32"E, L. Averyanov et 927 al. CPC6440 (LE); Tuyen Quang Province: Na Hang District, Vinh Yen Municipality, $928 \quad 22^{\circ} 21^{\prime} 14^{\prime \prime N} 105^{\circ} 25^{\prime} 11^{\prime \prime E}$, P.K. Loc et al. HLF-009 (HN).

\section{Elatostema macintyrei Dunn}

Bhutan, China, India, Thailand, Vietnam; 1000-1100 m.

Cao Bang Province: Bao Lac District, Xuan Truong Municipality, L.F. Fu et al.

VMN_CN807 (IBK, VNMN); Gia Lai Province: Mang Yang District, A Yun Municipality, Kon Ka Kinh National Park, 14¹3'17"N 108¹8'59"E, M.S. Nuraliev et al. 1492 (IBK, MW), M.S. District, 2309'06"N 105²4'59"E, L.F. Fu et al. VMN_CN185 (IBK, VNMN).

*Elatostema malacotrichum W.T.Wang \& Y.G.Wei

939 China, Vietnam; $400 \mathrm{~m}$.

940 Cao Bang Province: Ha Lang District, An Lac Municipality, $22^{\circ} 46^{\prime} \mathrm{N} 103^{\circ} 44^{\prime} \mathrm{E}, L$. 941 Averyanov et al. CBL607 (LE); Ha Quang District, Pac Bo, L.F. Fu et al. VMN_CN784 (IBK, 
942 VNMN).

943

944 Elatostema monandrum (Buch.-Ham. ex D.Don) H.Hara

945 Procris monandra Buch.-Ham. ex D.Don

946 Elatostema diversifolium Wedd., E. laetum Wedd., E. monandrum var. ciliatum (Hook.f.)

947 Murti, E. monandrum var. pinnatifidum (Hook.f.) Murti, E. monandrum var. serpens (Hook.f.)

948 Murti, E. monandrum var. zeylanicum (Hook.f.) Murti, E. muscicola W.T.Wang, E. surculosum

949 Wight, Pellionia mairei H.Lév.

950 Bhutan, China, India, Myanmar, Nepal, Sikkim, Sri Lanka, Thailand, Vietnam; 2000-2300 m.

$951 \quad$ Lao Cai Province: Sa Pa District, P.A. Petelot 5049 (P); Nghe An Province: Ky Son District, 952 Na Ngoi Municipality, 19¹1'58"N 104¹1'39"E, L. Averyanov et al. CPC6150(LE); 19¹2'23"N 953 104¹1'34"E, L. Averyanov et al. CPC6215 (LE).

954

Elatostema myrtillus (H.Lév.) Hand.-Mazz., Symb. Sin. 7(1): 146. 1929. Types: China. Pin-Fa, J. Cavalerie 559 (syntype: P!); Kouy-Tchéou, E. Bodinier 1548 (syntype: E); Kan-Yen-Tong, J. Esquirol 698 (syntype: E).

\section{Pellionia myrtillus H.Lév.}

Elatostema colaniae Gagnep., Bull. Soc. Bot. France 76: 81. 1929, syn. nov. Type: Vietnam. Lang Met, P.A. Colani 2927 (holotype: P!, isotype: P!).

China, Vietnam; 500-1600 m.

Bac Giang Province: Lang Met, P.A. Colani 2927 (P); Cao Bang Province: Tra Linh District, Quoc Toan Municipality, vicinity of Thang Heng and Lung Tao Villages, 22 ${ }^{\circ} 45^{\prime} 30^{\prime \prime} \mathrm{N}$ 106¹7'22"E, L. Averyanov et al. VH4855 (HN, LE); Tra Linh District, Quoc Toan Municipality, $22^{\circ} 45^{\prime} 15^{\prime \prime} \mathrm{N} 106^{\circ} 17^{\prime} 54^{\prime \prime E}$, D.K. Harder et al. 4312 (K); Ha Giang Province: between Meo Vac District and Dong Van District, 2315'02"N 105²3'09"E, L.F. Fu et al. VMN_CN197 (IBK, VNMN); Meo Vac District, Sung Cha Municipality, $23^{\circ} 11^{\prime} \mathrm{N} 105^{\circ} 17^{\prime} \mathrm{E}$, N.T. Hiep et al. NTH3287 (K, LE); Meo Vac District, Sung Cha Municipality, 2310'12"N 105¹7'39"E, L. Averyanov et al. 
969

970

971

972

973

974

975

976

977

978

979

980

981

982

983

984

985

986

987

988

989

990

991

992

993

994

995

HAL8490 (LE); Quan Ba District, Bat Dai Son Nature Reserve, Thanh Van commune, Mo Sai village, 2307'46"N 10457'56"E, L. Averyanov et al. VR409 (LE); Quan Ba District, Tung Vai Municipality, L.F. Fu et al. VMN_CN869(IBK, VNMN); Quan Ba District, Tung Vai Municipality, Thang village, $23^{\circ} 03^{\prime} 13^{\prime \prime} \mathrm{N} 104^{\circ} 51^{\prime} 49^{\prime \prime} \mathrm{E}$, L. Averyanov et al. VR742 (LE).

We place Elatostema colaniae in synonymy based on the same combination of characters as in E. myrtillus: small lamina $(13-28 \times 6-10 \mathrm{~mm})$ with auriculate base and furfuraceous stem base.

\section{*Elatostema nanchuanense W.T.Wang} China, Vietnam; 1050-1150 m.

Ha Giang province: Quan Ba District, Tung Vai Municipality, Thang village, $23^{\circ} 03^{\prime} 13^{\prime \prime} \mathrm{N}$ 104'51'49"E, L. Averyanov et al. VR552 (LE).

\section{Elatostema nasutum Hook.f.}

Elatostema hainanense W.T.Wang, E. stipulosum Hand.-Mazz. Bhutan, China, Nepal, Vietnam; 1100-2100 m.

Cao Bang Province: Nguyen Binh District, Nguyen Binh Municipality, 22³7'N 10552'E, L. Averyanov et al. CBL077, CBL171 (LE, MO); Nguyen Binh District, Phia Oac - Phia Den Nature Reserve, 2236'29"N 105'52'18"E, L.F. Fu et al. VMN_CN162 (IBK, VNMN); Ha Giang Province: Vi Xuyen District, Cao Bo Municipality, Tam Ve village, 2246'30"N 10449'01"E, D.K. Harder 5425 (MO); Yen Minh District, Du Gia Municipality, [2356'N 105¹3'E], P.K. Loc et al. CBL2028, CBL2080 (LE, MO); Kon Tum Province: Dak Glei District, N.T. Hiep et al. VH1757 (LE); Lai Chau Province: Than Uyen District, Ho Mit Municipality, 2206'N 10352'E, N.T. Hiep et al. NTH2669, NTH2812, NTH2874 (LE); Lao Cai Province: Sa Pa District, San Sa Ho, Sin Chai Municipality, 22²0'44.3"N 10348'77.0"E, V.X. Phuong et al. HNK470 (K); Nghe An Province: Ky Son District, Na Ngoi Municipality, 19¹1'59"N 104¹1'24"E, N.T. Hiep et al. CPC6286 (LE); Son La Province: Bac Yen District, Chu Village, 21ํ15'40.0"N 104²9'27.0"E, V.D. Nguyen et al. HNK2726 (K); Thanh Hoa Province: Thuong Xuan District, Bat Mot 
996 Municipality, 1958'18"N 10459'24"E, L. Averyanov et al. CPC6555 (LE); Vinh Phuc Province:

997 Tam Dao District, Tam Dao Range, N. Arnautov et al. LX-VN3858 (LE).

998

Elatostema neobaviense Y.H.Tseng \& A.K.Monro nom. nov.

1000 Pellionia baviensis Gagnep., Bull. Soc. Bot. France 75: 919. 1928. Type: Vietnam. Ha Noi

1001

City, Ba Vi District, Ba Vi Mountain, B. Balansa 2548 (lectotype: designated by Lin \& Yang, 1002 2010: 1912, P!).

1003 Endemic; elevation unknown.

1004 Ha Noi City: Ba Vi District, Ba Vi Mountain, B. Balansa 2548 (P).

1005 We select 'neobaviense' as epiphet as it takes the place of 'baviense' which would be in 1006 conflict with the homonym Elatostema baviensis.

Elatostema neriifolium W.T.Wang \& Z.Y.Wu

1009 China, Vietnam; 50-750 m.

Lao Cai Province: Sino-Vietnam Expedition 755 (PE); Quang Binh Province: Minh Hoa

District, Thuong Hoa Municipality, 17³9'22"N 10554'59"E, N.T. Hiep et al. CPC3819 (LE);

1012

Thanh Hoa Province: Ba Thuoc District, Co Lung Municipality, Khuyn village, 20²6'39"N

Tuyen Quang Province: Na Hang District, Thanh Tuong Municipality, 22 $166^{\prime} 26^{\prime \prime N} 105^{\circ} 25^{\prime} 58^{\prime \prime} \mathrm{E}$, P.K. Loc et al. HAL149(HN).

1016

1017

1018

1019

1020

1021

\section{*Elatostema oblongifolium S.H.Fu}

Pellionia bodinieri H.Lév. 
1023 (LE).

1024

1025 *Elatostema obtusum Wedd.

1026 Dorstenia pubescens Blanco, Elatostema delicatulum Wedd.

1027 Bhutan, China, India, Nepal, Sikkim, Thailand, Vietnam; 1400-1900 m.

1028 Cao Bang Province: Nguyen Binh District, Nguyen Binh Municipality, 22³7'N 10552'E, $L$. 1029 Averyanov et al. CBL206 (LE, MO, P); Lao Cai Province: Sa Pa District, Hoang Lien National 1030 Park, Ton Forest Station, L.F. Fu et al. VMN_CN971 (IBK, VNMN).

1031

1032

1033

1034

1035

*Elatostema oppositum Q.Lin \& Y.M.Shui

China, Vietnam; ca. $1100 \mathrm{~m}$.

1036

1037

Elatostema paucidentatum H.Schroet.

1038

a. Elatostema paucidentatum var. paucidentatum

1039 Pellionia paucidentata (H.Schroet.) Chien

1040

Elatostema henryanum var. oligodontum Hand.-Mazz., Pellionia longgangensis W.T.Wang, 1041 P. paucidentata var. hainanica Chien \& S.H.Wu, P. subundulata W.T.Wang.

1042

1043 China, Vietnam; 180-300 m.

1044

Cao Bang Province: Bao Lam District, Bac Mieu Municipality, L.F. Fu et al. VMN_CN827 (IBK, VNMN); Ha Giang Province: between Meo Vac District and Dong Van District, L.F. Fu et 1045 al. VMN_CN240(IBK, VNMN); Lai Chau Province: Muong Te District, Muong Te Municipality, 1046 $22^{\circ} 32^{\prime} 06^{\prime \prime N} 102^{\circ} 32^{\prime 2} 9^{\prime \prime E}$, N.T. Hiep et al. HAL10102, HAL10123 (LE); Lang Son Province: Lung District, Huu Lien Municipality, 21³9'31"N 106²2'06"E, D.E. Atha et al. NY-HN 73 (MO); Ninh Binh Province: Nho Quan District, Cuc Phuong National Park, 20¹7'33"N 105³9'54"E, 1049 D.D. Soejarto $10498(\mathrm{MO}), 20^{\circ} 17.55^{\prime} \mathrm{N} 105^{\circ} 39.90^{\prime} \mathrm{E}$, N.T. Hiep et al. 1998 (P); Quang Ninh 
1050 province: Dam Ha District, Lomg Ngong village, Sai Vong Mo Leng mt., W.T. Tsang 30277

1051 (SING); Ha-coi, near Chuk-phai, Taai Wong Mo Shan, W.T. Tsang 29166 (SING); Thai Nguyen

1052 Province: Vo Nhai District, Thuong Lung Municipality, 2148.75'N 10558.09'E, L.Q. Li et al.

10530078 (HN); Thanh Hoa Province: Quan Hoa District, Hien Chung Municipality, Xuan Lien

1054 Nature Reserve, F. Wen et al. VMN_CN413 (IBK, VNMN); Vinh Phuc Province: N. Arnautov et 1055 al. $L X-V N 3988(\mathrm{LE})$.

1056

1057

b. Elatostema paucidentatum var. dolichoceras W.T.Wang

1058 Endemic; 100-150 m.

1059

Lao Cai Province: Sino-Vietnam Expedition 590 (PE).

1060

1061

*Elatostema pergameneum W.T.Wang

1062

1063

China, Vietnam; 100-250 m.

1064

Lang Son Province: Huu Lung District, Huu Lien Municipality, 2140'59"N 106²0'30"E,

D.K. Harder et al. 4121 (K); Quan Binh Province: Minh Hoa District, 17²40'N 10557'E, L.

1065 Averyanov et al. VH4611 (HN).

1066

1067

Elatostema petelotii Gagnep.

1068

China, Vietnam; 260-1300 m.

1069

Cao Bang Province: Phia Oac, P.A. Petelot 720 (P); Ha Giang Province: between Meo Vac

1070

District and Dong Van District, L.F. Fu et al. VMN_CN239 (IBK, VNMN); Quan Ba District,

1071

Tung Vai Municipality, L.F.Fu et al.VMN_CN868(IBK, VNMN); Quan Ba District, Thang

1072

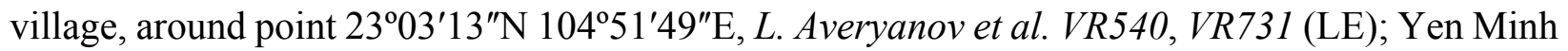

1073 District, Du Gia Municipality, 2356'N 105²13'E, P.K. Loc et al. CBL2022, CBL2024 (LE); Nghe

1074

An Province: Que Phong District, Hanh Dich Municipality, Pu Hoat Nature Reserve, 1945'19"N

1075

10447'45"E, M.S. Nuraliev 2142 (MW); Phu Tho Province: Thanh Son District, Xuan Son

1076 Municipality, V.X. Phuong $3930(\mathrm{HN})$. 
Elatostema platyphyllum Wedd., Arch. Mus. Hist. Nat. 9: 301. 1856. Type: India. Khasia, J.D.

1079

1080

1081

1082

1083

1084

1085

1086

1087

1088

1089

1090

1091

1092

1093

1094

1095

1096

1097

1098

1099

1100

1101

1102

1103

Hooker \& T. Thomoson s.n. (lectotype: designated by Lin, Duan \& Yang, 2009: 1912, K!).

E. platyphylloides B.L.Shih \& Yuen P.Yang, E. platyphyllum Wedd. var. polycephalum Hara. Elatostema baviensis Gagnep., Bull. Soc. Bot. France 76: 80. 1929, syn. nov. Type: Vietnam. Ha Noi City, Ba Vi District, Ba Vi Mountain, B. Balansa 2537 (holotype: P!).

Bhutan, China, India, Nepal, Philippines, Vietnam; 800-1669 m.

Gia Lai Province: K'Bang District, Song Lang Municipality, Kon Chu Rang Nature Reserve, 14³1'04"N 108³6'23"E, M.S. Nuraliev et al. 1996 (MW); Ha Giang Province: between Meo

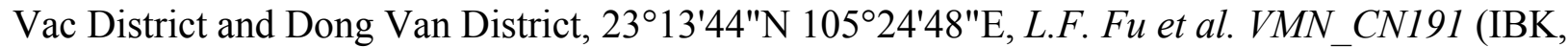

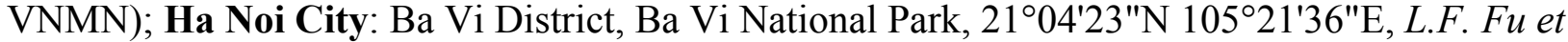
al.VMN_CN33 (IBK, VNMN), Ba Vi District, Ba Vi Mountain, B. Balansa 2537 (P); Ninh Binh Province: Nho Quan District, Cuc Phuong National Park, J.M. Hu Hu2122 (TAI); Thanh Hoa Province: Quan Hoa District, Hien Chung Municipality, Xuan Lien Nature Reserve, F. Wen et al. VMN_CN399,VMN_CN408(IBK, VNMN).

We place Elatostema baviensis in synonymy based on the same combination of characters as in E. platyphyllum: large lamina $(10-25 \times 4-7.5 \mathrm{~cm})$ with auriculate base, large stipule $(15-25 \times$ 3-5.5 mm) and pistillate inflorescence with short peduncle and obvious receptacle.

\section{*Elatostema prunifolium W.T.Wang}

China, Vietnam; elevation unknown.

Ha Giang Province: Quan Ba District, Tung Vai Municipality, L.F. Fu et al. VMN_CN866 (IBK, VNMN).

\section{Elatostema pseudodissectum W.T.Wang}

China, Vietnam; 1000-1300 m.

Cao Bang Province: Bao Lac District, Ca Thanh Municipality, $22^{\circ} 44^{\prime} \mathrm{N} 105^{\circ} 50^{\prime} \mathrm{E}, \mathrm{L}$. 
1104 Averyanov et al. CBL389 (LE, MO); Vinh Phuc Province: Tam Dao District, Tam Dao National 1105 Park, 2127'47"N 105³8'68"E, L.Q. Li et al. 559 (PE).

1106

1107

1108

1109

1110

1111

1112

1113

1114

1115

1116

1117

1118

1119

1120

1121

1122

1123

1124

1125

1126

1127

1128

1129

1130

*Elatostema pseudolongipes W.T.Wang \& Y.G.Wei

China, Vietnam; 150-600 m.

Bac Kan Province: Ba Be District, Nam Mau Municipality, Ba Be National Park, $22^{\circ} 26^{\prime} .875^{\prime} \mathrm{N} 106^{\circ} 37.028^{\prime} \mathrm{E}$, D.E. Atha et al. DA4722 (HN); Na Ri District, Liem Thuy Municipality, $21^{\circ} 57^{\prime} .36^{\prime} \mathrm{N} 106^{\circ} 04.622^{\prime} \mathrm{E}$, D.E. Atha et al. DA4773 (HN), Na Ri District, Kim Hy Municipality, $22^{\circ} 17^{\prime} \mathrm{N} 106^{\circ} 03^{\prime} \mathrm{E}$, N.T. Hiep et al. NTH3688, NTH3691 (LE); Cao Bang Province: Tra Linh District, Quoc Toan Municipality, Thang Heng vicinity and Lung Tao Villages, $22^{\circ} 45^{\prime} 30^{\prime \prime} \mathrm{N} 106^{\circ} 17^{\prime} 22^{\prime \prime E}$, L. Averyanov et al. VH4850, VH4928, VH4929 (HN, LE, MO); Ha

Giang Province: Bac Me District, Bac Me Nature Reserve, 2245'23"N 105¹3'46"E, L.F. Fu et al. VMN_CN221 (IBK, VNMN); Ninh Binh Province: Cuc Phuong National Park, L. Wu et al. VN0049 (HN, IBK); Quang Binh Province: Bo Trach District, Son Trach Municipality, 17³1'02"N 106¹6'48"E, L. Averyanov et al. HAL6382 (LE); Minh Hoa District, Thuong Hoa Municipality, 17³9'12"N 10554'53"E, N.T. Hiep et al. CPC3753 (LE); Tuyen Hoa District, Lam Hoa Municipality, $17^{\circ} 56^{\prime} 10^{\prime \prime} \mathrm{N} 105^{\circ} 4^{\prime} 15^{\prime \prime E}$, L. Averyanov et al. CPC2452 (LE); Thanh Hoa Province: Ba Thuoc District, Co Lung Municipality, Eo Dieu Village, 22²5'35"N 105²14'26"E, L. Averyanov et al. HAL3354 (HN).

\section{*Elatostema pycnodontum W.T.Wang}

China, Vietnam; 1400-1500 m.

Cao Bang Province: Bao Lac District, Dinh Phuong Municipality, 22 ${ }^{\circ} 47^{\prime} \mathrm{N} 105^{\circ} 49^{\prime} \mathrm{E}$, P.K. Loc et al. CBL1489 (LE, MO).

Elatostema radicans (Siebold \& Zucc.) Wedd.

Procris radicans Siebold \& Zucc. 
Pellionia arisanensis Hayata, P. cavaleriei H.Lév., P. chikushiensis Yamam., P. iseana (Makino ex Hatus.) Hatus. ex Kimura, Pellionia pauciflora W.T.Wang, P. radicans (Siebold \& Zucc.)

Wedd., P. radicans f. grandis Gagnep., P. radicans var. chikushiensis (Yamam.) S.S.Ying, P. radicans var. grandis (Gagnep.) W.T.Wang.

1136 China, Japan, Korea, Vietnam; 600-2700 m.

Cao Bang Province: Nguyen Binh District, Nguyen Binh Municipality, 22 $37^{\prime} \mathrm{N} 105^{\circ} 52^{\prime} \mathrm{E}, L$. Averyanov et al. CBL064 (HN, LE, MO); Nguyen Binh District, Phia Oac - Phia Den Nature Reserve, 22 36'29"N 105'52'18"E, L.F. Fu et al. VMN_CN160 (IBK, VNMN); Gia Lai Province:

K'Bang District, Son Lang Municipality, Kon Chu Rang Nature Reserve, 14³1'04"N

108³6'23"E, M.S. Nuraliev et al. 1994 (MW), 14³0'59"N 108³2'27"E, M.S. Nuraliev et al. 2019

(MW), 14³0'02"N 108³4'27"E, M.S. Nuraliev et al. 2027 (MW); Ha Giang Province: Meo Vac

District, vicinities of Meo Vac Town, $23^{\circ} 10^{\prime} \mathrm{N} 105^{\circ} 24^{\prime} \mathrm{E}$, N.T. Hiep et al. NTH3377 (LE); Khanh

Hoa Province: Khanh Son District, $12^{\circ} 12^{\prime} \mathrm{N} 108^{\circ} 44^{\prime} \mathrm{E}$, L. Averyanov et al. VH4353 (LE, MO);

Kon Tum Province: L. Averyanov et al. VH543 (LE, MO); Lam Dong Province: Lac Duong

District, Da Chais Municipality, 1209'N 10841'E, L. Averyanov et al. VH2890, VH2914 (LE),

Province: Sino-Vietnam Expedition 1597 (PE); Lao Cai Province: Sa Pa District, Hoang Lien 10400'37"E, L. Averyanov et al. HAL2094 (LE), 21 ${ }^{\circ} 59^{\prime} 04^{\prime \prime} \mathrm{N} 104^{\circ} 15^{\prime} 08^{\prime \prime} \mathrm{E}$, L. Averyanov et al. Binh, $12^{\circ} 07^{\prime} \mathrm{N} 108^{\circ} 41^{\prime} \mathrm{E}$, L. Averyanov et al. VH3369 (HN, LE); Quang Binh Province: Minh Hoa District, Dan Hoa Municipality, 17²5'27"N 10547'46"E, L. Averyanov et al. HAL12539 
1158 Arnautov et al. LX-VN3941 (LE); Tam Dao District, 21²8'02"N 105³8'39"E, L.F. Fu et al.

1159 VMN_CN50 (IBK, VNMN); Tam Dao National Park, N. Arnautov et al. LX-VN3859, LX-VN3859,

1160 LX-VN3920, LX-VN4045 (LE), L. Averyanov 65-A (LE).

1161

1162

Elatostema ramosum W.T.Wang

1163

Elatostema ramosum var. villosum W.T.Wang.

1164 China, Vietnam; 500-1400 m.

1165

Cao Bang Province: Nguyen Binh District, Yen Lac Municipality, 2245'34"N 10551'49"E,

1166

L. Averyanovet al. CPC5424 (LE); Ha Giang Province: Bac Me District, Bac Me Nature Reserve, 1167 2245'14"N 105¹3'36"E, L.F. Fu et al. VMN_CN227 (IBK, VNMN); Quan Ba District, Bat Dai

Son commune, Bat Dai Son Nature Reserve, San Chu village, $23^{\circ} 08^{\prime} 55^{\prime \prime} \mathrm{N} 104^{\circ} 59^{\prime} 46^{\prime \prime} \mathrm{E}, L$.

Averyanov et al. VR065 (LE); Hoa Binh Province: Lac Son District, Tu Do Municipality, 20²5'29"N 105¹9'36"E, N.Q. Hieu et al. CPC1559 (LE); Ninh Binh Province: Cuc Phuong

National Park, T.H. Nguyen NTH 3015 (MO); Nho Quan District, Cuc Phuong National Park, J.M. Ни Нu2065 (TAI).

\section{Elatostema retrohirtum Dunn}

China, Vietnam; 87-1100 m.

Bac Kan Province: Na Ri District, Kim Hy Nature Reserve, 22¹1'49"N 10603'51"E, L.F.

Fu et al. VMN_CN120(IBK, VNMN); Gia Lai Province: K'Bang District, Son Lang Municipality,

Kon Chu Rang Nature Reserve, 1430'55"N 108³2'48"E, M.S. Nuraliev 2009 (MW); Ha Giang

Province: Bac Me District, Bac Me Nature Reserve, 2245'24"N 105¹3'49"E, L.F. Fu et al. VMN_CN217 (IBK, VNMN); between Meo Vac District and Dong Van District, L.F. Fu et al. VMN_CN186,VMN_CN196,VMN_CN245(IBK, VNMN); Quan Ba District, Tung Vai Municipality, L.F. Fu et al. VMN_CN864 (IBK, VNMN); Ha Noi City: Ba Vi District, Ba Vi National Park, $21^{\circ} 04^{\prime} 22^{\prime \prime N} 105^{\circ} 21^{\prime} 36^{\prime \prime E}$, L.F. Fu et al. VMN_CN34 (IBK, VNMN), 21 ${ }^{\circ} 03^{\prime} 35^{\prime \prime} \mathrm{N}$ 105²1'50"E, M.S. Nuraliev 1917 (IBK, MW); Hai Phong City: Cat Hai District, Cat Ba Island, 
1185 Cat Ba National Park, Frog pond, 2048.005'N 107²1.600'E, N.A. Vislobokov 13030 (MW); Hoa

1186 Binh Province: Lac Son District, Ngoc Son Municipality, 20²6'31"N 105¹9'32"E, N.Q. Hieu et 1187 al. CPC1615 (LE); Lam Dong Province: Bao Loc, L. Averyanov et al. LX-VN1713 (LE); Nghe 1188 An Province: Que Phong District, Hanh Dich Municipality, Pu Hoat Nature Reserve, 1946'19"N 1189 10447'00"E, M.S. Nuraliev 2180 (MW); Ninh Binh Province: Nho Quan District, Cuc Phuong 1190 National Park, J.M. Hu Hu2099 (TAI); Son La Province: Phu Yen District, Gia Phu Municipality, 1191 Nhet Village, 2136'27.7"N 10404'22.8"E, V.D. Nguyen et al. HNK2469 (K); Tuyen Quang 1192 Province: Na Hang District, Vinh Yen Municipality, 22²1'07"N 105²5'06"E, N.T. Hiep et al. $1193 \quad H L F-229(\mathrm{HN})$.

1194

Elatostema rhizomatosum (Gagnep.) Q.Lin Pellionia rhizomatosa Gagnep. Endemic; ca. $500 \mathrm{~m}$. Province unknown: Annam, col des Nuages prés Tourane, M. Poilane 7909 (P).

Elatostema rupestre (Buch.-Ham. ex D.Don) Wedd. Procris rupestris Buch.-Ham. ex D.Don. Elatostema zollingerianum Miq.

*Elatostema salvinioides W.T.Wang

a. Elatostema salvinioides var. robustum W.T.Wang China, Vietnam; 1100-1650 m.

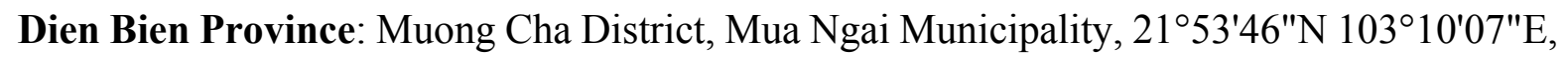
1210 L. Averyanov et al. CPC1048, CPC1920 (LE); Lai Chau Province: Sin Ho District, Ta Ngau Municipality, $22^{\circ} 18^{\prime} \mathrm{N} 103^{\circ} 15^{\prime} \mathrm{E}$, N.T. Hiep et al. NTH2772 (LE). 
1213 Elatostema scabrum (Benth.) Hallier f.

$1214 \quad$ Pellionia scabra Benth.

1215 Elatostema pellioniifolium W.T.Wang, Pellionia cephaloidea W.T.Wang, P. scabra subvar. 1216 pedunculata Yamam., Polychroa scabra (Benth.) Hu.

1217 China, Japan, Vietnam; 700-1800 m.

1218 Hoa Binh Province: Da Bac District, Cao Son Municipality, Buoi Truong station, 1219 2054'09"N 105¹2'15"E, N.T. Hiep et al. HAL592 (HN); Kon Tum Province: L. Averyanov et al. 1220 VH255 (HN, LE, MO); Phu Tho Province: Tan Son District, Xuan Son Municipality, 21 $066^{\prime} 49^{\prime \prime} \mathrm{N}$ 1221 10456'03"E, L. Averyanov et al. HAL12749 (LE); Son La Province: Yen Chau District, Muong 1222 Lum Municipality, 2059'06"N 104²8'46"E, D.K. Harder et al. 7298 (HN).

1223

1224

1225

1226

1227

1228 1229

1230

1231

1232

1233

1234

1235

1236

1237 1238

\section{Elatostema simplicissimum Q.Lin}

Pellionia imbricata Gagnep.

Endemic; 200-220 m.

Lai Chau Province: $22^{\circ} 03^{\prime} \mathrm{N} 103^{\circ} 09^{\prime} \mathrm{E}$, N.T. Hiep et al. NTH2747 (LE); Muong Lay District, Nam Hang Municipality, 22 $08^{\prime} 14^{\prime \prime N} 102^{\circ} 58^{\prime} 18^{\prime \prime E}$, D.K. Harder et al. 5884 (K, LE).

Elatostema sinense H.Schroet.

Elatostema sinense var. trilobatum W.T.Wang.

China, Vietnam; ca. $500 \mathrm{~m}$.

Ha Giang Province: Bac Me District, Bac Me Nature Reserve, L.F. Fu et al. VMN_CN216A (IBK, VNMN); Quan Ba District, Tung Vai Municipality, L.F. Fu et al. VMN_CN872 (IBK, VNMN); Hoa Binh Province: Mai Chau District, Pa Co Municipality, F. Wen et al. VMN_CN330, VMN_CN333 (IBK, VNMN); Son La Province: Bac Yen District, Ta Sua Municipality, Chu Village, $21^{\circ} 15^{\prime} 40.0^{\prime \prime} \mathrm{N} 104^{\circ} 29^{\prime} 27.0^{\prime \prime E}$, V.D. Nguyen et al. HNK2724 (K). 
1239

1240

1241

1242

1243

1244

1245

1246

1247

1248

1249

1250

1251

1252

1253

1254

1255

1256

1257

1258

1259

1260

1261

1262

1263

1264

1265

Elatostema sublineare W.T.Wang

China, Vietnam; elevation unkown.

Cao Bang Province: Bao Lac District, Dinh Phung Municipality, L.F. Fu et al. VMN_CN815

(IBK, VNMN); Lang Son Province: Van Lang District, Anon. 1036 (LE); Ninh Binh Province:

Nho Quan District, Cuc Phuong National Park, J.M. Hu Hu2106 (TAI); Tuyen Quang Province:

Na Hang District, Anon. TV-74 (HN).

Elatostema tenuicaudatum W.T.Wang

China, Vietnam; 240-1700 m.

Cao Bang Province: Bao Lac District, Xuan Truong Municipality, L.F. Fu et al.

VMN_CN808 (IBK, VNMN); Dak Lak Province: Krong Bong District, Cu Pui Municipality, $12^{\circ} 30^{\prime} \mathrm{N} 108^{\circ} 30^{\prime} \mathrm{E}$, L. Averyanov et al. VH6036 (HN); Dien Bien Province: Muong Cha District,

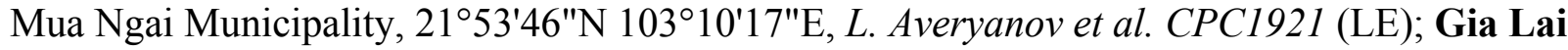

Province: Mang Yang District, A Yun Municipality, Kon Ka Kinh National Park, 14²13'10"N 108¹9'10"E, M.S. Nuraliev et al. 1827 (IBK, MW); Ha Giang Province: Vi Xuyen District, Cao Bo Municipality, Tam Ve village, 2246'03"N 10449'42"E, D.K. Harder et al. 5454 (MO), 2246'12"N 10449'33"E, D.K. Harder et al. 5370 (MO); Yen Minh District, Du Gia Municipality, [235'서 10313'E], P.K. Loc et al. CBL2063 (LE); Hoa Binh Province: Lac Son District, Tu Do Municipality, 20²6'07"N 105¹7'19"E, N.Q. Hieu et al. CPC1499 (LE); Khanh Hoa Province: Khanh Son District, $12^{\circ} 12^{\prime} \mathrm{N} 108^{\circ} 44^{\prime} \mathrm{E}$, L. Averyanov et al. VH4313 (HN, LE, MO); Lam Dong Province: Lac Duong District, Da Chais Municipality, $12^{\circ} 09^{\prime} \mathrm{N} 108^{\circ} 41^{\prime} \mathrm{E}$, L. Averyanov et al. VH2891 (HN, LE, MO), $12^{\circ} 07^{\prime} \mathrm{N} 108^{\circ} 41^{\prime} \mathrm{E}$, L. Averyanov et al. VH3413 (LE), $12^{\circ} 11^{\prime} \mathrm{N} 108^{\circ} 43^{\prime} \mathrm{E}$, L. Averyanov et al. VH4387 (LE, MO); Lao Cai Province: Van Ban District, Khanh Yen Ha Municipality, 21 $57^{\prime} 59^{\prime \prime N} 104^{\circ} 14^{\prime} 06^{\prime E}$, L. Averyanov et al. HAL2462 (HN, LE); Van Ban District, Nam Xe Municipality, 2201'27"N 10400'25"E, D.K. Harder et al. DKH7060 (LE); Phu Tho Province: Tan Son District, Xuan Son Municipality, 21 $06^{\prime} 57^{\prime \prime} \mathrm{N} 104^{\circ} 57^{\prime} 17^{\prime \prime E}$, L. Averyanov et al. HAL12639 (LE); Quang Nam Province: L. Averyanov et al. VH905 (HN, LE); Tuyen Quang 
1266 Province: Na Hang District, Vinh Yen Municipality, 22²1'09"N 105²5'20"E, Le Van Cham et al. 1267 HLF-061 (HN); Vinh Phuc Province: Tam Dao District, 21²7'35"N 105³8'58"E, L.F. Fu et al. 1268 VMN_CN45(IBK, VNMN); Tam Dao Range, N. Arnautov et al. LX-VN3921 (LE).

Elatostema trichosanthum (Gagnep.) H.Schroet. Pellionia trichosantha Gagnep. Endemic; elevation unknown.

Elatostema tsoongii (Merr.) H.Schroet. Polycharoa tsoongii Merr. Pellionia cristulata Gagnep. Cambodia, China, Vietnam; 115-1100 m.

\section{a. Elatostema tsoongii ssp. tsoongii}

Bac Kan Province: Na Ri District, Kim Hy Nature Reserve, $22^{\circ} 18^{\prime} 01^{\prime \prime} \mathrm{N} 106^{\circ} 01^{\prime} 38^{\prime \prime} \mathrm{E}$, L.F. Municipality, $12^{\circ} 30^{\prime} \mathrm{N} 108^{\circ} 30^{\prime} \mathrm{E}$, L. Averyanov et al. VH5928 (HN); Lak District, Bong Krang Municipality, Chu Yang Sin National Park, 12²3'50"N 108²1'00"E, M.S. Nuraliev 997 (K, MW); Gia Lai Province: Mang Yang District, A Yun Municipality, Kon Ka Kinh National Park, 14²12'53"N 108¹8'56"E, M.S. Nuraliev et al. 1449 (IBK, MW); Ha Tinh Province: Huong Son District, Son Hong Municipality, 18³4'06"N 105¹1'40"E, P.K. Loc et al. HAL5193 (HN, LE);

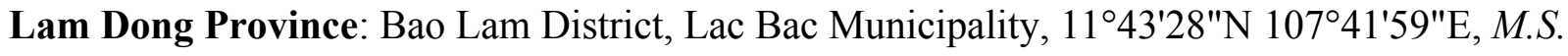
Nuraliev et al. s.n. (photo: MW); Lang Son Province: Huu Lung District, Huu Lien Municipality, Huu Lien Protected Area, 2140'59"N 106²0'30"E, D.K. Harder et al. 4120 (K); Pac Mo District, Anon. 1149 (LE); Quang Binh Province: Minh Hoa District, Thong Hoa Municipality, vicinities of Yen Son Village, $17^{\circ} 40^{\prime} \mathrm{N} 105^{\circ} 57^{\prime} \mathrm{E}$, L. Averyanov et al. VH4729 (HN, LE, MO); Quang Tri Province: Da Krong District, Ta Rut Municipality, 16²4'29"N 10701'07"E, L. Averyanov et al. 
1293 CPC3017 (LE); Lang Khoai, Polilane 10741 (P); Thanh Hoa Province: Quan Hoa District, Pu 1294 Hu Nature Reserve, F. Wen et al. VMN_CN352 (IBK, VNMN); Thua Thien Hue Province: Phu 1295 Loc District, Bach Ma National Park, 16²14'11"N 10744'28"E, N.T. Hiep et al. HLF1649 (HN, 1296 MO); Tuyen Quang Province: Na Hang District, Thanh Tuong Municipality, near Ban Bung 1297 Village, 22¹6'26"N 105²5'58"E, P.K. Loc et al. HAL164 (HN); Vinh Phuc Province: Tam Dao 1298 National Park, N. Arnautov et al. LX-VN4005 (LE).

b. Elatostema tsoongii ssp. subpeltatum (Gagnep.) H.W.Li

1301 Pellionia subpeltata Gagnep. China, Vietnam; elevation unknown.

Bac Giang Province: Lang Met, P.A. Petelot 2929 (P).

Elatostema veronicoides (Gagnep.) H.Schroet. Pellionia veronicoides Gagnep. China, Vietnam; elevation unknown.

Elatostema vietnamense Q.Lin \& L.D.Duan Endemic; elevation unknown. 1314 (PE). China, Vietnam; 400-1450 m.

Bac Kan Province: Na Ri District, Kim Hy Nature Reserve, 22 11'56"N 10604'05"E, L.F. 1319 Fu et al. VMN_CN134 (IBK, VNMN); Na Ri District, Kim Hy Nature Reserve, Y.G. Wei \& V.T. 
1320

1321

1322

1323

1324

1325

1326

1327

1328

1329

1330

1331

1332

1333

1334

1335

1336

1337

1338

1339

1340

1341

1342

1343

1344

Do VMN_CN24 (IBK, VNMN); Ha Giang Province: Quan Ba District, 23066'57"N 10501'47"E,

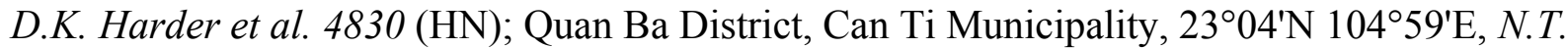

Hiep et al. NTH3614 (K); Quan Ba District, San Chu village, 2308'55"N 10459'46"E, L.

Averyanov et al. VR063 (LE); Quan Ba District, Thanh Van commune, Mo Sai village, 2307'46"N

104'57'56"E, L. Averyanov et al. VR394 (LE); Son La Province: Van Ho District, Tan Xuan

Municipality, 2040'33"N 104³9'00"E, L. Averyanov et al. CPC7117 (LE).

\section{*Elatostema xichouense W.T.Wang}

China, Vietnam; 300-1100 m.

Ha Giang Province: Quan Ba District, Bat Dai Son Nature Reserve, 230'서 $104^{\circ} 59^{\prime} \mathrm{E}$, D.K. Harder et al. 5120 (HN), L. Averyanov et al. VR052 (LE), N.T. Hiep \& L. Averyanov 5120 (MO); Quan Ba District, Bat Dai Son Nature Reserve, Thanh Van commune, Mo Sai village, 230. $7^{\prime} 46^{\prime \prime} \mathrm{N}$ 104 57'56"E, L. Averyanov et al. VR365 (LE); Meo Vac District, L.F. Fu et al. VMN_CN852(IBK, VNMN); Hoa Binh Province: Lac Son District, Tu Do Municipality, 20²6'07"N 105¹7'19"E, N.Q. Hieu et al. CPC1482 (LE); Mai Chau District, Van Mai Municipality, 20³5'26"N $105^{\circ} 02^{\prime} 00^{\prime \prime E}$, D.K. Harder et al. 8170 (MO); Ninh Binh Province: Nho Quan District, Cuc Phuong National Park, L. Averyanov et al. $L X$-VN1728 (LE).

\section{Excluded taxa}

Elatostema cuneatum Wight

Elatostema approximatum Wedd., E. densiflorum Franch. \& Sav., E. nipponicum Makino., E. webbianum Wedd.

Bhutan, China, India, Indonesia, Laos, Thailand.

This species was indicated by Ho (2003) and Hiep (2005) as occurring in Vietnam but no specimen was cited and we were unable to locate any specimen from Vietnam. 


\section{Table $\mathbf{1}$ (on next page)}

The species richness, endemism, and new records identified per Floristic Region

the data indicates a summary of the species richness, national endemism, and new national records identified here, per floristic region. 
1 Table 1. The species richness, endemism, and new records identified per Floristic Region

\begin{tabular}{llll}
\hline Floristic Region & Species no. & Endemic species no. & New records no. \\
\hline Sikang-Yunnan Floristic Region & 36 & 2 & 9 \\
South Chinese Floristic Region & 54 & 5 & 12 \\
North Indochinese Floristic Region & 36 & 1 & 4 \\
Central Annamese Floristic Region & 16 & 2 & 0 \\
South Annamese Floristic Region & 7 & 0 & 0 \\
South Indochinese Floristic Region & 0 & 0 & 0 \\
\hline
\end{tabular}
2 


\section{Figure 1}

\section{Climate map of Vietnam}

the data based on Nguyen et al. 2000 showing seven types of climate in Vietnam 


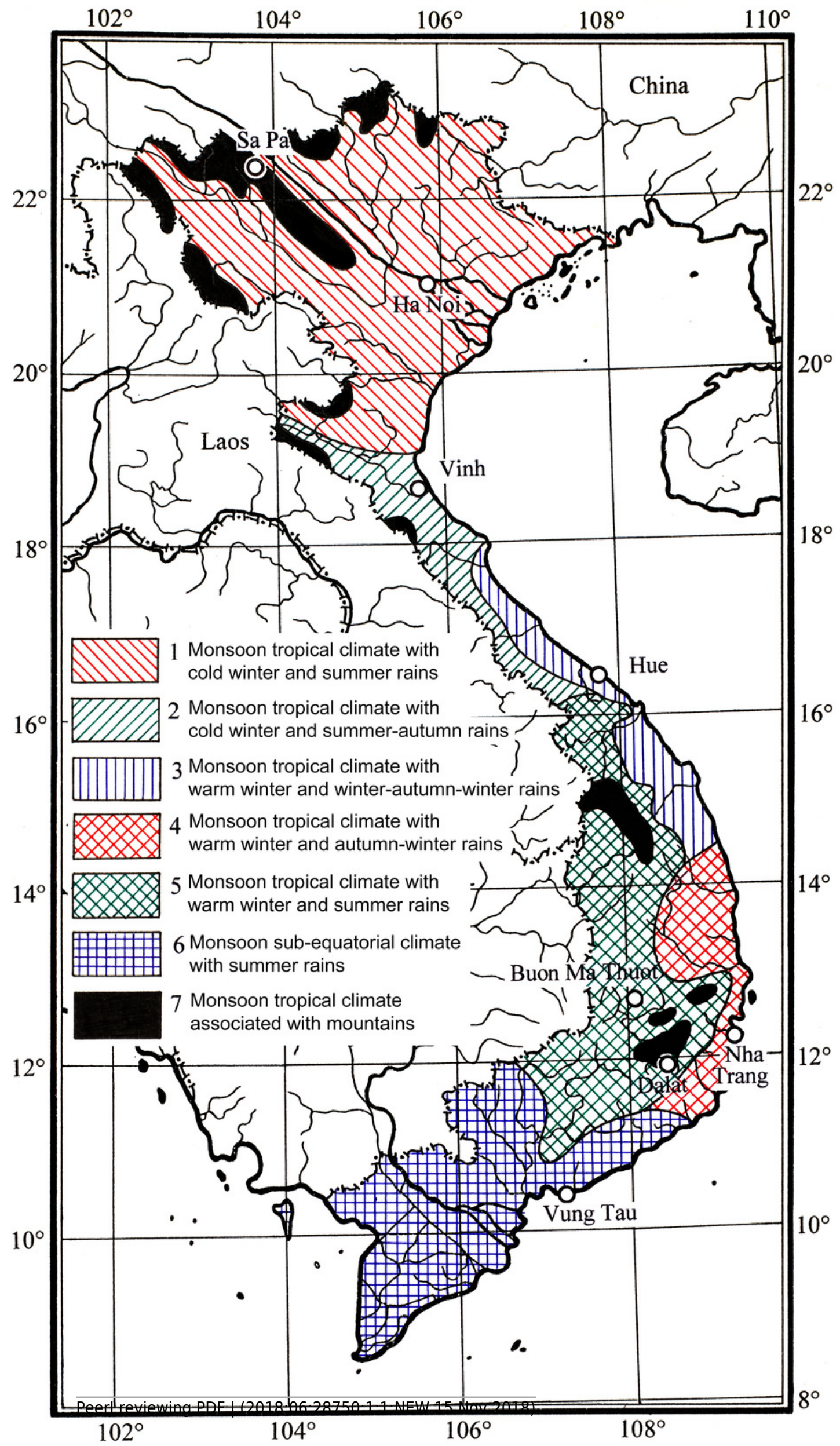


Figure 2

Map of floristic regions in Vietnam

the data modified from Averyanov et al. 2003c showing six floristic regions in Vietnam 


\section{Sikang-Yunnan}

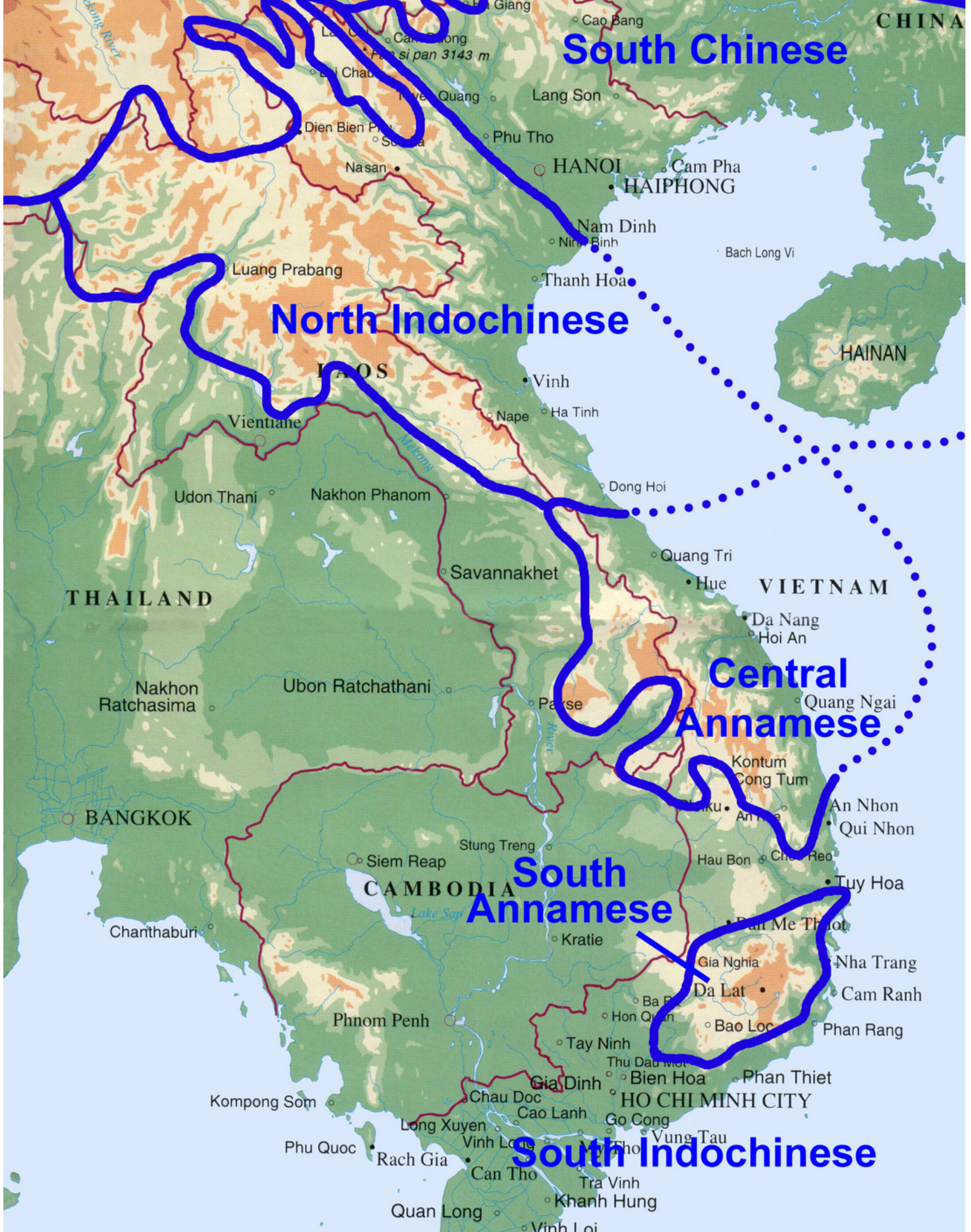




\section{Figure 3}

Plate I of representative Elatostema species in Vietnam: A, E. crassiusculum; B, E. glochidioides; C, E. hookerianum; D, E. prunifolium; E, E. arcuatobracteatum; F, E. retrohirtum; $\mathrm{G}, \mathrm{E}$. obtusum; $\mathrm{H}$, [i]E. ra

The data showed representative Elatostema species in Vietnam.
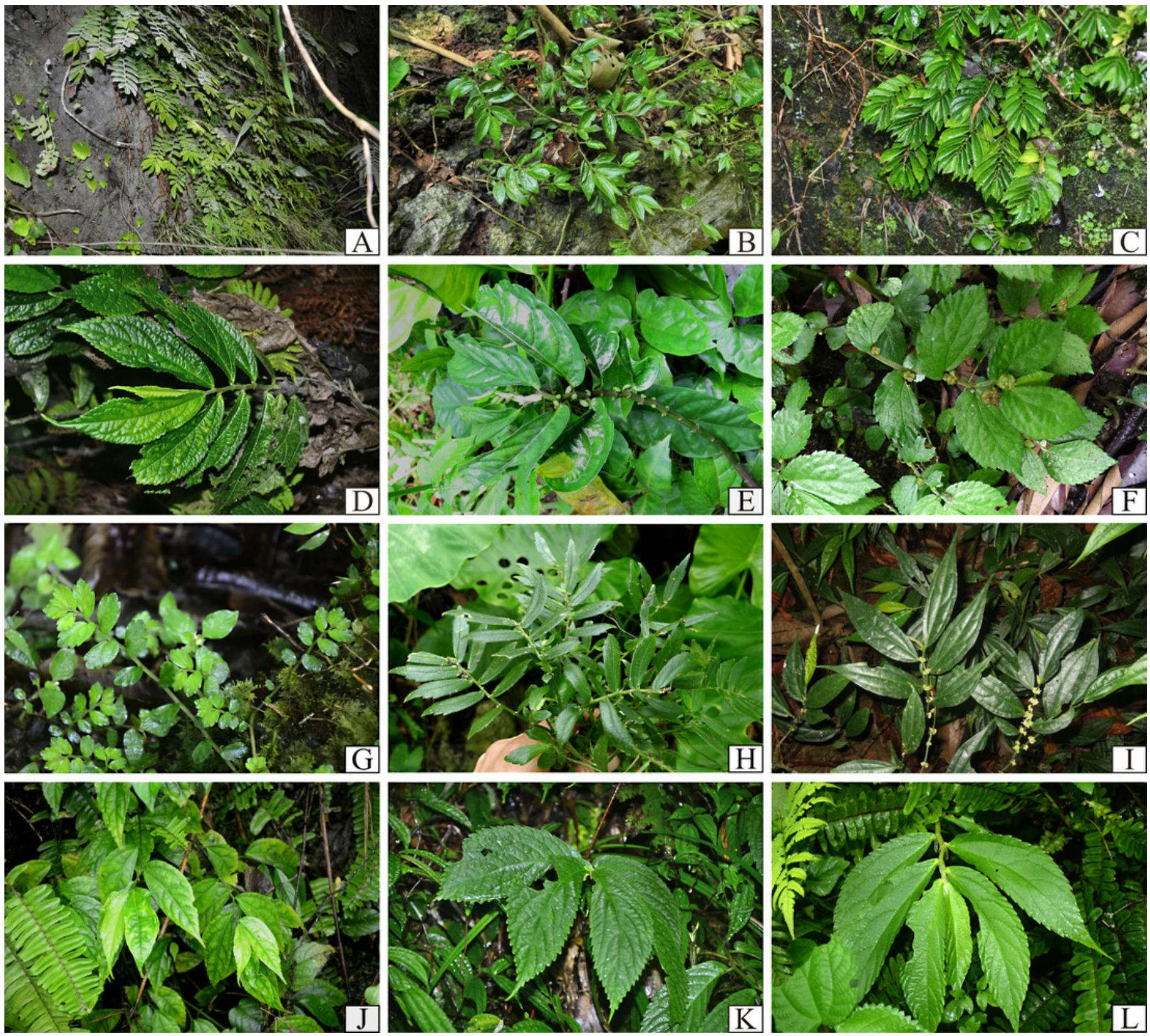


\section{Figure 4}

Plate II of representative Elatostema species in Vietnam: A, E. heterolobum; B, E. atroviride; C, E. tenuicaudatum; D, E. nasutum; E, E. cyrtandrifolium; F, E. backeri; $G, E$. veronicoides; $\mathrm{H}$, [i]E. dissectum

The data showed representative Elatostema species in Vietnam.
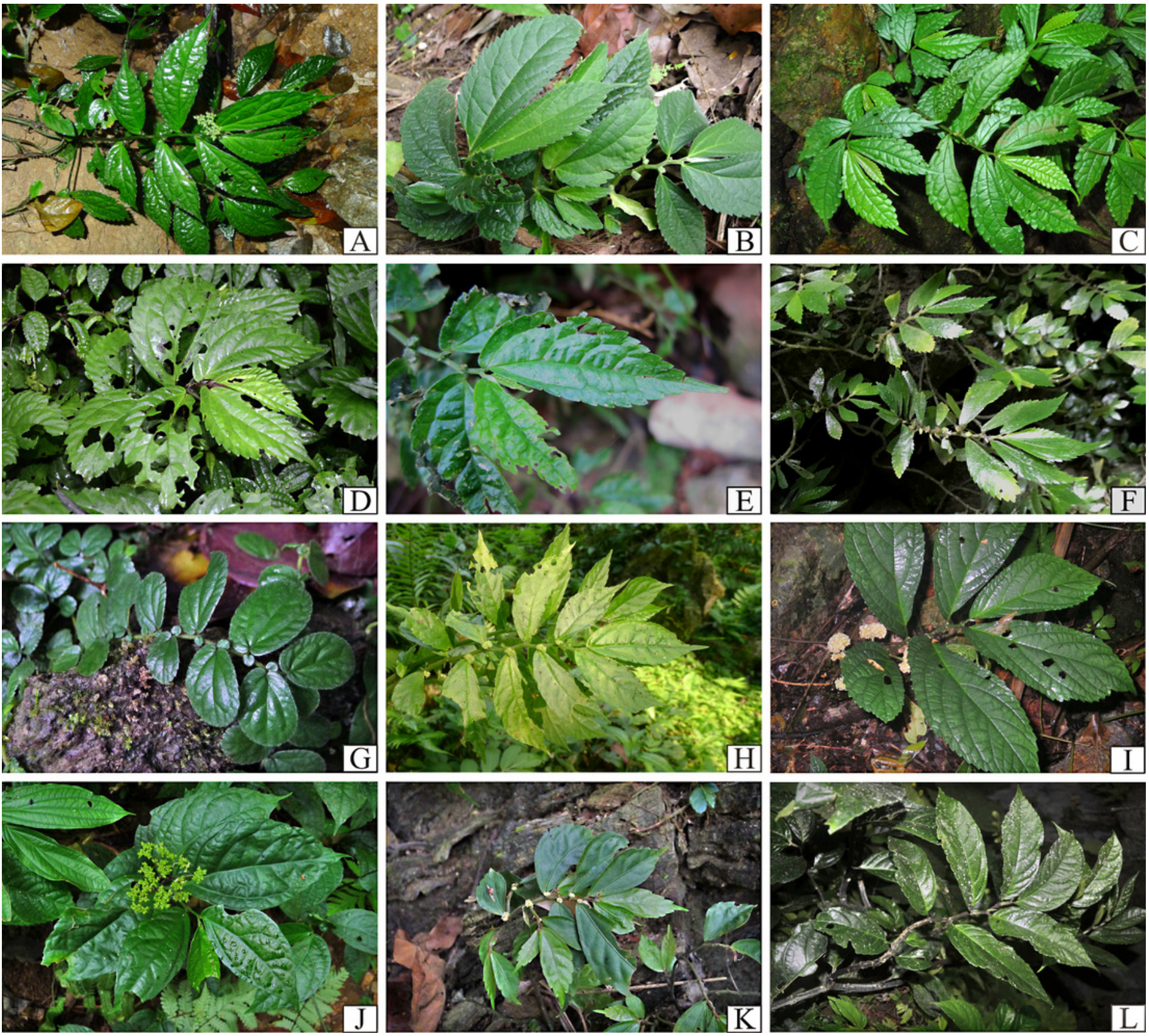


\section{Figure 5}

Plate III of representative Elatostema species in Vietnam: A, E. caulialatum; B, E. radicans; $C, E$. tsoongii; $D, E$. sinense; $E, E$. brevifolium; $F, E$. macintyrei; $G, E$. balansae; $\mathrm{H}$, E. myrtillus; I, [i]

The data showed representative Elatostema species in Vietnam
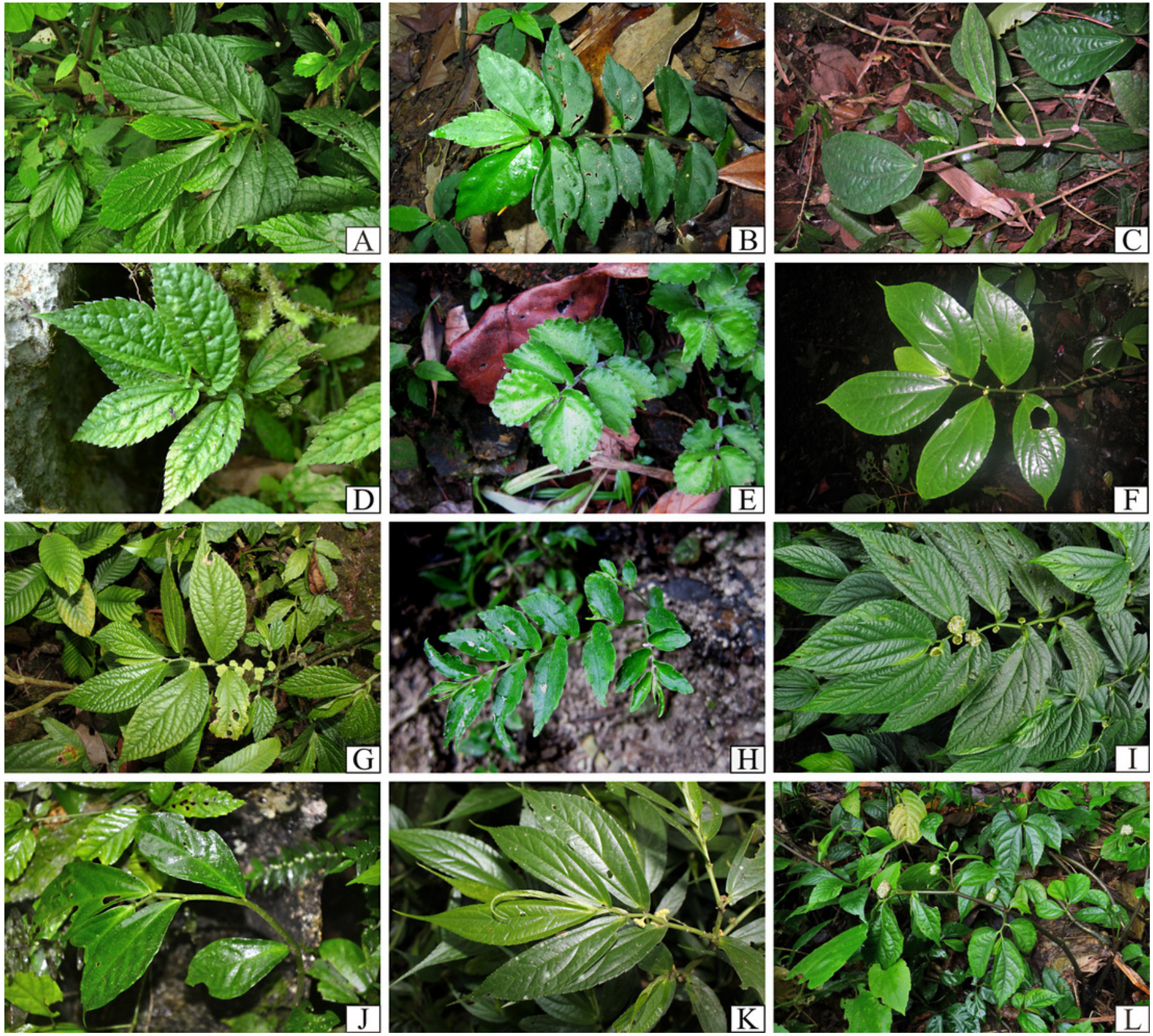


\section{Figure 6}

Variation in Elatostema species richness and endemism across provinces of Vietnam

The data showed the diversity and endemism of Elatostema in each Province of Vietnam 


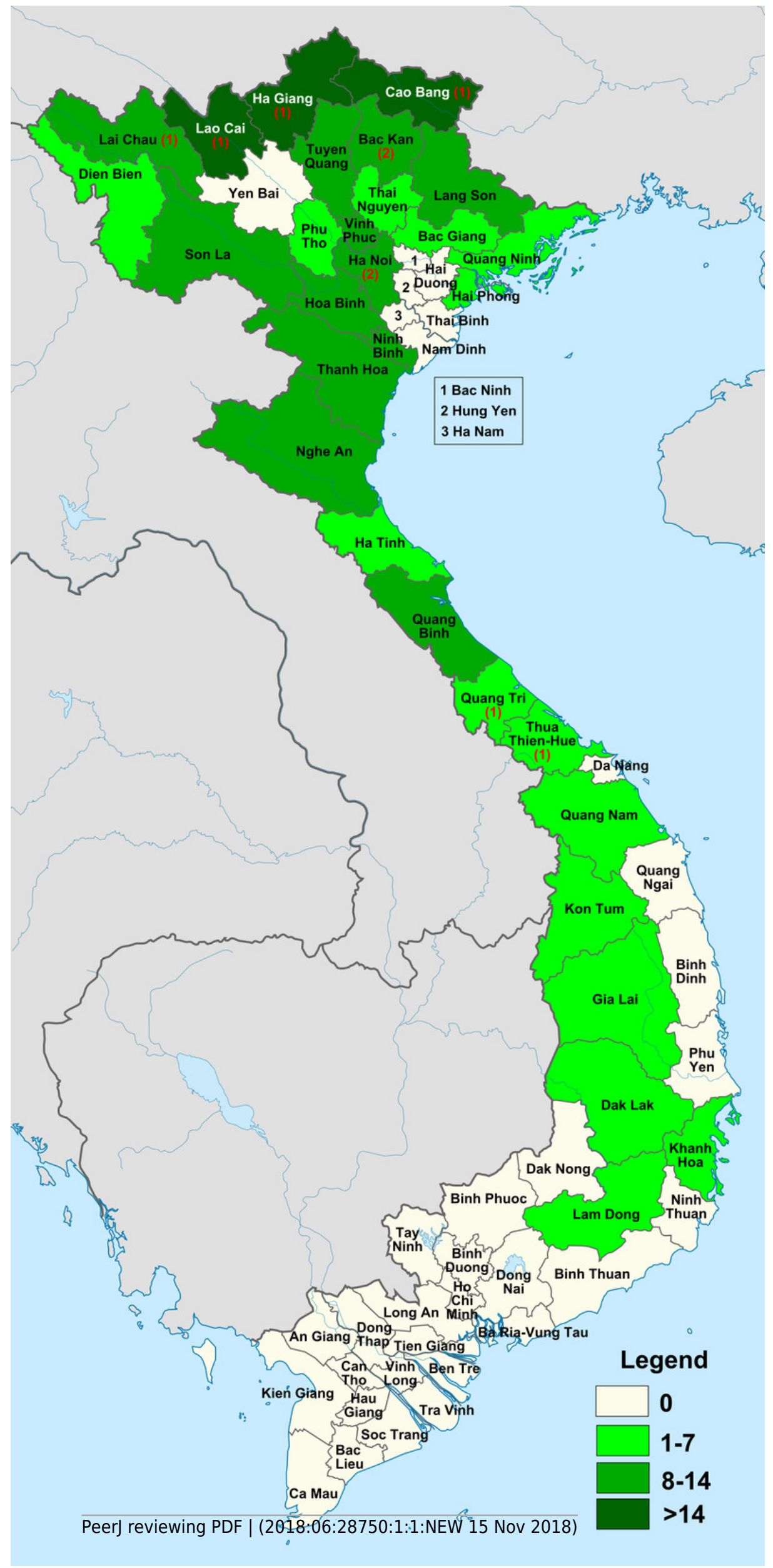




\section{Figure 7}

Proportion of diversity and endemism and the relationship of the floristic regions

Large circles designate floristic regions. Percentage numbers above the line in the large circles indicate the relative proportion of diversity occurring in a certain region (within Vietnam); percentage numbers below the line indicate the relative proportion of national endemics occurring in a certain region; percentage numbers in the small circles indicate the relative proportion of co-exsisted species occurring in the pairs of region connected by the line and show their relative floristic relationships 


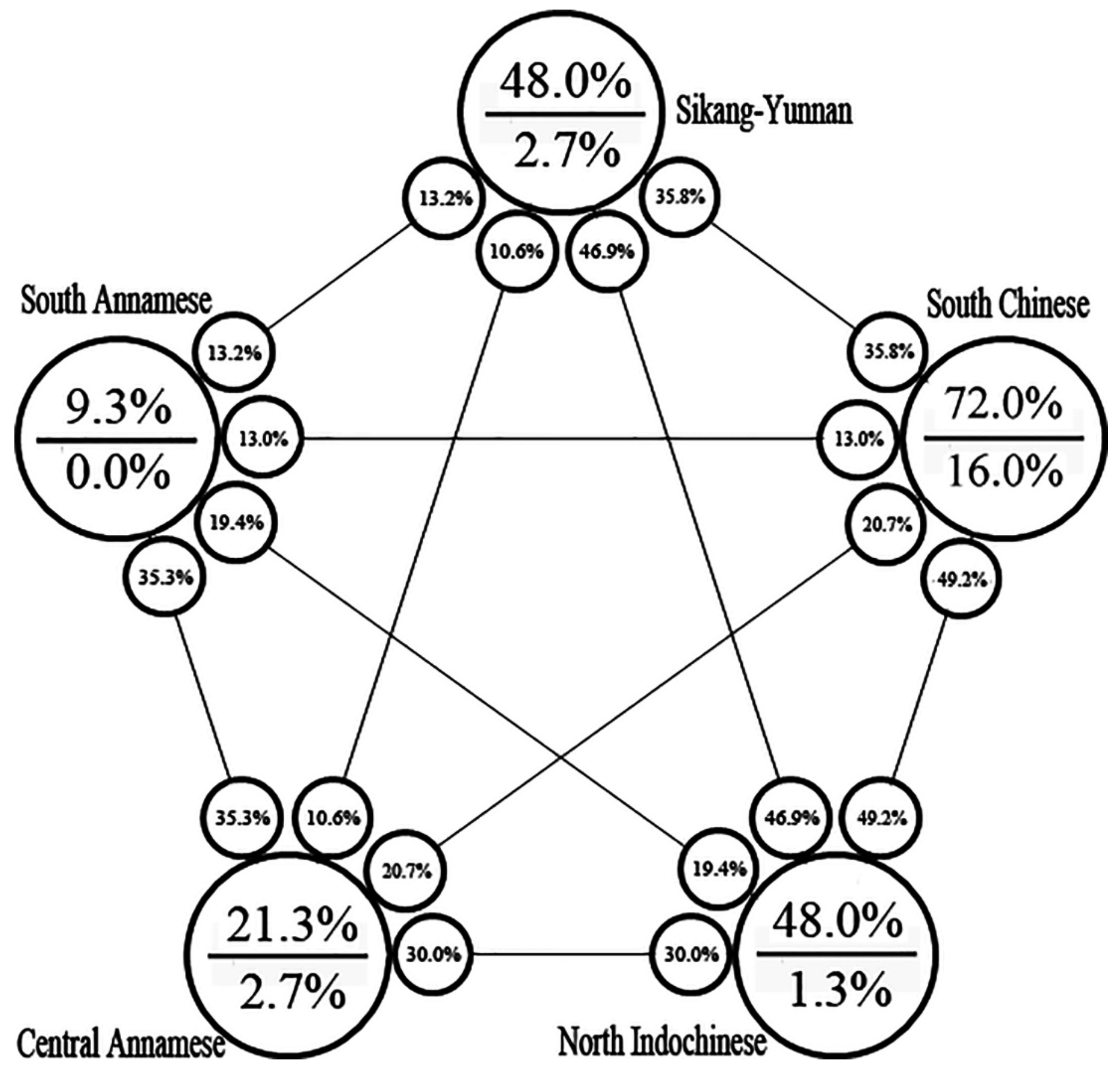

